\title{
Removal of Heavy Metals during Primary Treatment of Municipal Wastewater and Possibilities of Enhanced Removal: A Review
}

\author{
Ida Sylwan *(i) and Eva Thorin *(1)
}

Citation: Sylwan, I.; Thorin, E. Removal of Heavy Metals during Primary Treatment of Municipal Wastewater and Possibilities of Enhanced Removal: A Review. Water 2021, 13, 1121. https://doi.org/ 10.3390/w13081121

Academic Editors: Cristina Palet and Julio Bastos-Arrieta

Received: 30 March 2021

Accepted: 16 April 2021

Published: 19 April 2021

Publisher's Note: MDPI stays neutral with regard to jurisdictional claims in published maps and institutional affiliations.

Copyright: (c) 2021 by the authors. Licensee MDPI, Basel, Switzerland. This article is an open access article distributed under the terms and conditions of the Creative Commons Attribution (CC BY) license (https:// creativecommons.org/licenses/by/ $4.0 /)$.
Future Energy Center, School of Business, Society and Engineering, Mälardalen University, SE-721 23 Västerås, Sweden

* Correspondence: ida.sylwan@mdh.se (I.S.); eva.thorin@mdh.se (E.T.); Tel.: +46-(0)-21-151-767 (I.S.); +46-(0)-21-101-564 (E.T.)

\begin{abstract}
Resource reuse has become an important aspect of wastewater management. At present, use of sludge in agriculture is one of the major reuse routes. Conventional municipal wastewater treatment does not involve any designated process for removal of heavy metals, and these distribute mainly between effluent and sludge. Enhanced removal of heavy metals during primary treatment may decrease the heavy metal concentrations in both effluent and sludge from secondary treatment and promote long-term reuse of secondary sludge. This review considers heavy metal occurrence and removal during primary settling, together with possible treatment technologies for heavy metal removal in primary settlers and their theoretical performance. The variation in total heavy metal concentrations and dissolved fraction in raw municipal wastewater points to a need for site-specific assessments of appropriate technologies for improved heavy metal removal. Studies examining the heavy metal speciation beyond dissolved/particulate are few. Missing or disparate information on process parameters such as hydraulic retention time, $\mathrm{pH}$ and composition of return flows makes it hard to generalize the findings from studies concerning heavy metal removal in primary settlers. Coagulation/flocculation and use of low-cost sorbents were identified as the most promising methods for enhancing heavy metal removal during primary settling. Based on the available data on heavy metal speciation and removal during primary settling, sorption technologies may be most effective for enhancing the removal of $\mathrm{Cu}$ and $\mathrm{Ni}$, while coagulation may be efficient for $\mathrm{Cd}, \mathrm{Cr}, \mathrm{Cu}, \mathrm{Pb}, \mathrm{Zn}$ and $\mathrm{Hg}$ removal (but not as efficient for Ni removal).
\end{abstract}

Keywords: primary settling; resource reuse; sludge; effluent; adsorption; coagulation/flocculation

\section{Introduction}

Heavy metals, referring to a group of high-density elements including metals and metalloids, are a concern due to elevated concentrations in the natural environment as a result of anthropogenic activities [1]. One of the anthropogenic sources is wastewater. Heavy metals include biologically essential elements such as copper $(\mathrm{Cu})$, chromium $(\mathrm{Cr})$, zinc ( $\mathrm{Zn})$, nickel (Ni), boron (B), iron (Fe) and molybdenum (Mo), and elements which are not essential such as lead $(\mathrm{Pb})$, mercury $(\mathrm{Hg})$, cadmium $(\mathrm{Cd})$, arsenic (As) and silver (Ag). Most heavy metals are toxic to humans even in low amounts. Heavy metals may induce disease to the gastrointestinal, renal, cardiovascular systems, etc., including conditions such as cancer, liver and kidney disease, melancholy and osteoporosis. Heavy metal contamination can also affect plant metabolism and growth [2].

To achieve environmental sustainability, reuse of nutrients, energy and, in some cases, water has become an important aspect of wastewater management [3]. Wastewater treatment, through physical, chemical and biological processes generates treated water (effluent), solid residues (sludge) and gaseous emissions. Degradation of heavy metals is not possible, which means that the majority of influent heavy metals will distribute 
between effluent and sludge, though heavy metals such as $\mathrm{Hg}$, As and the semi-metal antimony $\mathrm{Sb}$ can form volatile compounds which are transferred to the gaseous phase $[4,5]$. Safe reuse of nutrients from sludge and water requires that associated toxic substances such as heavy metals are minimized. Use of sludge in agriculture is currently the most common option for reuse of nutrients [6], while the most common option for reuse of water is for irrigation and landscaping [7].

Industrial emissions historically were the main source of heavy metals entering municipal wastewater. However, stringent legislation for industrial emission caused heavy metals to decrease markedly during the 1970s and the early 1980s [4]. Based on the current trends of heavy metals' contents in sludge, it was deduced that in some places, diffuse emissions currently constitute the main contribution of heavy metals [8]. Diffuse emission sources include corrosion of pipes and roofs (containing $\mathrm{Cu}$ ) and runoff from streets (where asphalt, tires and brake linings may contain $\mathrm{Cd}, \mathrm{Pb}$ and $\mathrm{Zn}$ ). Furthermore, the use of amalgam for fixing teeth was estimated to contribute a large part of $\mathrm{Hg}$, and food was calculated to contribute $9 \%$ of $\mathrm{Cd}$ and $25 \%$ of $\mathrm{Zn}$ in a municipal wastewater treatment plant (WWTP) in Stockholm, Sweden [8].

In order to continue the reduction in heavy metals in sludge and effluent, there is a need to regulate the use of heavy metals in different products further. Meanwhile, it is also relevant to attempt to optimize wastewater treatment systems for minimization of heavy metals in sludge and effluent [4]. Yoshida et al. [5] modelled the ecotoxicity and toxicity impact on humans from municipal wastewater. They found that the heavy metal $\mathrm{Zn}$ contributed the largest share of toxic impact with regards to both effluent release and sludge use in agriculture. However, they also found that conventional treatment of wastewater significantly reduced the toxicity exposure from inorganic constituents (including heavy metals) on freshwater and seawater. According to Hospido et al. [9], terrestrial ecotoxicity due to heavy metal content in sludge together with eutrophication are the most significant factors in terms of environmental impact from municipal wastewater treatment.

Several reviews $[4,10,11]$ considered heavy metal removal during conventional municipal wastewater treatment and discussed the importance of assessing heavy metal contents in end products from municipal wastewater treatment: effluent water and sludge. Conventional treatment here refers to primary settling followed by the activated sludge process (ASP) or biological nutrient removal (BNR). Hargreaves et al. [12] reviewed current heavy metal removal and performance of additional treatment processes for enhanced removal to minimize heavy metal concentrations in effluents (not considering heavy metal elimination from sludge). Possible technologies for enhancing the removal of heavy metals during primary settling were not reviewed previously. Increased heavy metal removal during or directly following primary settling (as a separate treatment step) could potentially decrease the heavy metal concentrations in the treated effluent and in the sludge from subsequent biological treatment.

Environmental background concentrations, together with regulations and standards for heavy metal concentration in freshwater, irrigation water and drinking water, are summarized in Table 1 and compared to typical concentrations in municipal wastewater in Europe. Heavy metal concentrations in WWTP influent are generally higher compared to the concentrations of heavy metals found in natural water (background). In Europe, environmental quality standards (EQS) for freshwater were implemented to preserve/attain good ecological and chemical status in all surface- and groundwater, based on the goals of the Water Framework Directive [13]. EQS for $\mathrm{Pb}, \mathrm{Cd}, \mathrm{Ni}$ and $\mathrm{Hg}$ exist on the central European level [14], while priority substances identified on the national level led to an extended list of EQS with stricter limits, as exemplified by Swedish regulation [15]. Raw municipal wastewater generally contains higher concentrations of heavy metals compared to both central and local EQS; however, effluent concentrations (after treatment) may not exceed the EQS. In relation to standards and regulation for drinking water and irrigation water, heavy metal concentrations in municipal wastewater do not always exceed the limits. 
Background heavy metal concentrations and limiting values for heavy metals in soil and sludge used in agriculture are summarized in Table 2 and compared to typical concentrations in sludge from municipal WWTPs in Europe. European heavy metal limits for sludge use in agriculture [16] are more stringent compared to US limits. The current European legislation is more than 30 years old. Several member states have implemented more strict limits. Updated legislation was drafted on the central European level but not yet implemented. The drafted proposal includes stricter limits for heavy metals and an addition of limit values for synthetic organic contaminants and indicator organisms [17]. Based on the heavy metal concentrations occurring in sludge from European WWTPs, reuse of sludge is partly limited by current legislation, especially in relation to the stricter regulation in some countries.

This review focuses on heavy metal removal during primary treatment of municipal wastewater, with the purpose of reducing heavy metal contents in effluent and in sludge from subsequent biological treatment (secondary sludge). The review includes: (i) occurrence and speciation of heavy metals in raw municipal wastewater (influent to primary settlers), (ii) mechanisms of heavy metal removal during primary settling, (iii) possible treatment technologies for enhanced heavy metal removal in or directly following primary settling, (iv) calculations to estimate theoretical heavy metal removal if enhanced heavy metal removal was introduced based on current removal of particulate and dissolved heavy metals during primary settlement.

\section{Material and Methods}

In this study, findings on heavy metal removal during primary treatment of municipal wastewater in previous published scientific publications are summarized. The findings are also related to current and planned regulations for water in different parts of the world. Experimental data collected from previous studies were analyzed by correlations of data with respect to heavy metal concentrations and heavy metal removal during primary settling (Sections 4.4 and 7). Further, the potential for improved removal of dissolved and particulate heavy metals was estimated (further details given in Section 7.1).

\section{Occurrence of Heavy Metals in Wastewater and Sludge}

Based on current legislation, it is relevant to optimize wastewater treatment to reduce heavy metal concentrations in both sludge and effluent. It should be noted that, while concentrations in sludge may directly limit the possibilities of sludge reuse in agriculture, effluent release is not directly prohibited by concentrations exceeding EQS, since the dilution of effluent discharge is considered [18] Gardner et al. [19] showed that dilution of $\mathrm{Zn}, \mathrm{Cd}, \mathrm{Cu}$ and $\mathrm{Ni}$ was required for some of UK's WWTPs to meet the national EQS or so called "predicted no effect concentration". The scope of this review includes the metals listed in Tables 1 and 2 (for which water-related regulations and standards exist), and Ag (for which a limiting value was proposed in Sweden) [20]. 


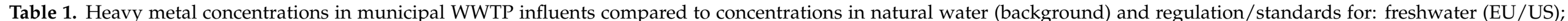

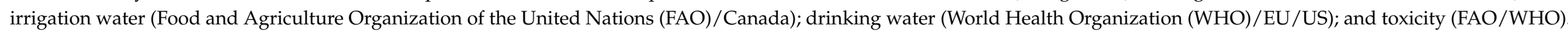

\begin{tabular}{|c|c|c|c|c|c|c|c|c|c|c|}
\hline \multirow{2}{*}{ Metal } & \multirow{2}{*}{$\begin{array}{l}\text { Background } \\
\quad(\mu \mathrm{g} / \mathrm{L})\end{array}$} & \multicolumn{2}{|c|}{ Freshwater $(\mu \mathrm{g} / \mathrm{L})$} & \multirow{2}{*}{$\begin{array}{c}\begin{array}{c}\text { Irrigation } \\
\text { Water }(\mu \mathrm{g} / \mathrm{L})\end{array} \\
\text { FAO }\end{array}$} & \multirow{2}{*}{ Canada } & \multirow{2}{*}{$\begin{array}{c}\begin{array}{c}\text { Drinking } \\
\text { Water }(\mu \mathrm{g} / \mathrm{L})\end{array} \\
\text { WHO }\end{array}$} & \multirow{2}{*}{$\mathrm{EU}^{\mathrm{b}}$} & \multirow{2}{*}{ US } & \multirow{2}{*}{$\begin{array}{c}\text { Typical Municipal } \\
\text { WWTP Influent } \\
\text { Concentrations }(\mu \mathrm{g} / \mathrm{L}) \\
\text { Europe } \\
\text { (Number of Plants) c }\end{array}$} & \multirow{2}{*}{$\begin{array}{c}\begin{array}{c}\text { Toxicity } \\
\text { (mg/kg Body } \\
\text { Weight) }\end{array} \\
\text { FAO/WHO } \\
\end{array}$} \\
\hline & & $\begin{array}{l}\text { EQS in Sweden } \\
\text { (EU Central EQS) }^{a}\end{array}$ & $\begin{array}{l}\text { Water Quality } \\
\text { Criteria in the US }\end{array}$ & & & & & & & \\
\hline As & $0.13-2.71$ & $7(-)$ & - & 100 & 100 & 10 & 10 & 10 & $2.7-12(15)$ & $\begin{array}{l}\text { Withdrawn } \\
\text { (previous: } \\
0.0021 \text { daily) }\end{array}$ \\
\hline $\mathrm{Cd}$ & $6 \times 10^{-4}-0.61$ & $\begin{array}{c}0.08-0.25 \\
(0.08-0.25)\end{array}$ & - & 10 & 5 & 3 & 5 & 5 & $0.4-75(18)$ & 0.025 monthly \\
\hline $\mathrm{Cr}$ & $0.29-11.46$ & $12(-)$ & - & 100 & $\mathrm{Cr}^{6+}: 8, \mathrm{Cr}^{3+}: 5$ & 50 & 50 & 100 & 8-100 (17) & - \\
\hline $\mathrm{Cu}$ & $0.23-2.59$ & $8.2(-)$ & $0.18-20^{\mathrm{e}}$ & 200 & $200^{f}$ & 2000 & 2000 & 1300 & 10-100 (18) & 0.500 daily \\
\hline $\mathrm{Pb}$ & $0.007-308$ & $0.34(1.2-1.3)$ & $0.01-7^{\mathrm{e}}$ & 5000 & 200 & 10 & 10 & 15 & $2-100(18)$ & $\begin{array}{c}\text { Withdrawn } \\
\text { (previous: } 0.025 \\
\text { weekly) }\end{array}$ \\
\hline $\mathrm{Hg}$ & - & $0.05\left(0.07^{g}\right)$ & 0.77 & - & - & 6 & 1 & 2 & $0.7-3.6(6)$ & 0.004 \\
\hline $\mathrm{Zn}$ & $0.27-27$ & $7.8(-)$ & $2.4-260^{\mathrm{e}}$ & 2000 & $\begin{array}{c}1000 \\
(\mathrm{pH}<6.5)\end{array}$ & - & - & - & $100-1600(17)$ & 1 daily \\
\hline Reference & [1] & {$[14,15]$} & [12] & [1] & [1] & [1] & [1] & [1] & [4] & [1] \\
\hline
\end{tabular}

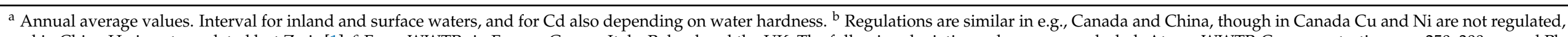

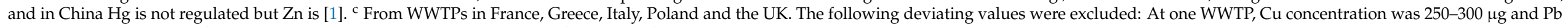

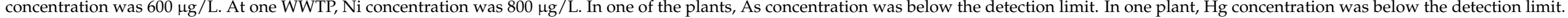

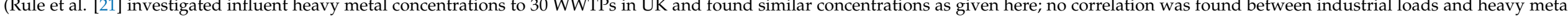

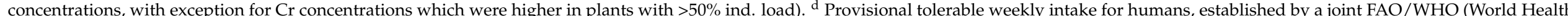

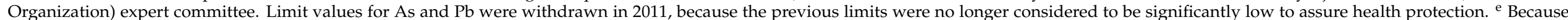
bioavailibility of heavy metals varies e.g., due to hardness, criteria is different depending on the hardness of the water. ${ }^{\mathrm{f}} 1000 \mu \mathrm{g} / \mathrm{L}$ for tolerant crops. ${ }^{\mathrm{g}}$ Maximum allowable concentration. 


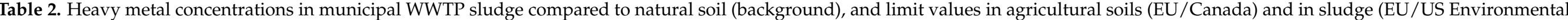
Protection Agency (EPA)) when sludge is used in agriculture (d.w. stands for dry weight).

\begin{tabular}{|c|c|c|c|c|c|c|c|c|c|}
\hline \multirow{2}{*}{ Metal } & \multirow{2}{*}{$\begin{array}{c}\begin{array}{c}\text { Background } \\
\text { (mg/kg) }\end{array} \\
\text { Upper Crust }\end{array}$} & \multirow{2}{*}{ Surface Soil } & \multicolumn{2}{|c|}{$\begin{array}{l}\text { Agricultural Soils } \\
\text { (mg/kg d.w.) }\end{array}$} & \multicolumn{4}{|c|}{ Sludge for Agricultural Use (mg/kg d.w.) } & \multirow{2}{*}{$\begin{array}{c}\begin{array}{c}\text { Typical Municipal WWTP } \\
\text { Sludge Concentrations } \\
\text { (mg/kg d.w.) }\end{array} \\
\begin{array}{c}\text { Europe (Number of } \\
\text { Plants) }\end{array} \\
\end{array}$} \\
\hline & & & $\begin{array}{c}\text { EU, Directive } \\
\text { 86/278/EEC } \\
\text { (Soil pH 6-7) }\end{array}$ & Canada & $\begin{array}{c}\text { EU, Directive } \\
\text { 86/278/EEC }\end{array}$ & $\begin{array}{c}\text { EU Countries with } \\
\text { More } \\
\text { Stringent Limits a }\end{array}$ & $\begin{array}{l}\text { EU Countries with } \\
\text { Far More } \\
\text { Stringent Limits b }\end{array}$ & $\begin{array}{c}\text { US, EPA/ } \\
\text { Federal } \\
\text { Regulation }\end{array}$ & \\
\hline As & 1.8 & 4.7 & - & 12 & - & $20-150^{d}$ & $25^{\mathrm{e}}$ & 75 & $4.2-40.4(6)$ \\
\hline $\mathrm{Cd}$ & 0.1 & 0.41 & $1-3$ & 1.4 & $20-40$ & $2-10$ & $0.8-2$ & 85 & $1.0-22(11)$ \\
\hline $\mathrm{Cr}$ & 35 & 42 & - & 64 & - & $70-1000$ & $75-100$ & - & $15.3-856(10)$ \\
\hline $\mathrm{Pb}$ & 15 & 25 & $50-300$ & 70 & $750-1200$ & $45-900$ & $100-120$ & 840 & $3.1-330(11)$ \\
\hline $\mathrm{Hg}$ & 0.07 & 0.07 & $1-1.5$ & 6.6 & $16-25$ & $2-10$ & $0.75-2.5$ & 57 & $0.9-3.2(6)$ \\
\hline $\mathrm{Ni}$ & 19 & 18 & $30-75$ & 45 & $300-400$ & $25-200$ & $30-50$ & 420 & $16.6-621(10)$ \\
\hline $\mathrm{Zn}$ & 52 & 62 & $150-300$ & 200 & $2500-4000$ & $200-3000$ & $300-800^{f}$ & 7500 & $501-8900(11)$ \\
\hline Reference & [1] & [1] & [1] & [1] & [16] & [4] & [4] & {$[4]$} & [4] \\
\hline
\end{tabular}

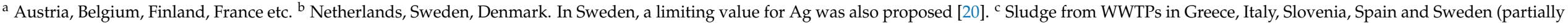
industrial load, which ranged from 6-70\%, though not given in all cases). ${ }^{\mathrm{d}}$ Limit values for as only apply in Austria (20) and Belgium (150). ${ }^{\mathrm{e}}$ As limit only in Denmark. ${ }^{\mathrm{f}}$ In Denmark: Cu: $1000, \mathrm{Zn}$ : 4000. 


\section{Heavy Metal Speciation in Raw Municipal Wastewater}

The speciation of heavy metals, i.e., the knowledge of which heavy metal ions and complexes are present in which amounts, is important for the potential removal of heavy metals during primary treatment. Heavy metal speciation is affected by hardness, alkalinity, $\mathrm{pH}$ and redox potential of the wastewater [10]. The heavy metal speciation in influent wastewater is of importance for the possible removal of heavy metals through different technologies. For example, in the case of sorption processes, dissolved heavy metals can be sorbed, while heavy metals bound to wastewater particles may only interact with an added sorbent if desorption first occurs or if wastewater particles form agglomerates with the sorbent. Heavy metals associated with particulate matter can be removed through settling or filtration if the particles are large enough.

\subsection{Different Definitions Applied with Respect to Heavy Metal Speciation in Municipal Wastewater}

A number of studies concerning heavy metal load in raw wastewater and distribution of heavy metals between sludge and effluents in WWPTs examined the total heavy metal concentrations without further specifying the speciation of heavy metals [5,21-32]. However, there is also a number of studies where partitioning of heavy metals between the particulate and dissolved phase was determined (e.g., Choubert et al. [33] and Toumi et al. [34]). The distinction between dissolved and particulate matter in wastewater is generally based on size fractioning of the wastewater, where the fraction which passes through a filter of certain pore size is defined as dissolved. A filter with pore size of $0.45 \mu \mathrm{m}$ is most commonly used; however, in some cases, other pore sizes were applied, e.g., $0.2 \mu \mathrm{m}[35,36]$. What are referred to as "dissolved" heavy metals are analyzed after filtering the wastewater, while the "particulate" heavy metals are calculated as the difference between the total heavy metal concentration (analyzed in unfiltered wastewater) and the dissolved heavy metals.

According to Ziolko et al. [10], heavy metals are likely to occur as organometallic complexes, and should be considered in the following three groups: surface-bonded organic ligands, insoluble matter and soluble organic ligands. Truly dissolved heavy metal ions are considered rare. Heavy metals associated with the dissolved phase $(<0.45 \mu \mathrm{m})$ may be associated with chelating agents of natural origin (e.g., proteins and nucleic acids) or synthetic origin (e.g., nitrilotriacetic acid and ethylenediamine tetraacetic acid (EDTA) [10]. El Samrani et al. [37] examined the different mineral forms of heavy metals in overflow wastewater from a combined collection system for municipal wastewater and stormwater (also called combined sewer overflow). They found that heavy metals associated with sulfide particles were abundant. These were assumed to be formed within the sewer network. Heavy metals were also encountered in the form of alloys, iron oxihydroxides, carbonates, phosphates and sulphates, and associated with clays. The abundance of heavy metal-bearing sulfides was confirmed by [38].

Further knowledge on the speciation of heavy metals could enhance the understanding of heavy metal removal mechanisms. Some attempts were made to elucidate the heavy metal speciation in municipal wastewater. Lawson et al. [36] performed gel chromatography of synthetic wastewater for separation of heavy metal species. Buzier et al. [39] and Gourlay-Francé et al. [40] analyzed the dissolved heavy metals in two different fractions, inert or labile. Buzier et al. [39] described the labile heavy metals as "inorganic metal fraction with a possible additional contribution of small weak organic complexes", while Gourlay-Francé et al. [40] simply described the labile fraction as "truly dissolved in water". The dissolved inert fraction is associated with dissolved organic matter (DOM), which Buzier et al. [39] described as "strong metal complexes and large weak organic complexes". The analysis of heavy metals by Gourlay-Francé et al. [40] and Buzier et al. [39] was performed subsequent to separation of heavy metals species by diffusion and dissociation into a permeable gel.

The dissolved fraction $(<0.45 \mu \mathrm{m})$ may also be considered to consist of heavy metals associated with colloids and truly dissolved heavy metals. The distinction between the two is based on molecular weight, where the truly dissolved fraction is the fraction smaller than 
$1 \mathrm{kDa}$ (1000 Dalton), and colloidal matter is defined by the interval $1 \mathrm{kDa}-0.45 \mu \mathrm{m}$. The organic matter in the truly dissolved size fraction is primarily composed of humic substances, while the colloidal fraction is primarily composed of non-humic macromolecules, including proteins, polysaccharides and aminosugars (which may be associated with nucleic acids) [41].

\subsection{Influence of Return Flows on Heavy Metal Speciation}

Influent wastewater to primary settlers is commonly mixed with return flows from sludge treatment (thickening and/or dewatering), in which the heavy metal speciation may differ from the speciation in influent wastewater. These return flows are not always considered when calculating the removal of heavy metals over primary clarification or mass balances over whole WWTPs (e.g., Karvelas et al. [35]). However, return flow of sludge liquors was shown to contribute to significant amounts of heavy metals entering primary settlement, according to Goldstone et al. [42-44]. Most of these heavy metals were associated with solids. According to a mass balance study of a Danish WWTP, the amount of heavy metals from return of centrate from sludge dewatering constituted a significant fraction of the heavy metals entering primary treatment: $8 \%$ of $\mathrm{Cd}, \mathrm{Cr}, \mathrm{Pb}$ and $\mathrm{Zn} ; 12 \%$ of $\mathrm{Cu}$ and $5 \%$ of $\mathrm{Ni}$ (estimated from graph) [5]. Innaa et al. [45] investigated mass flows of $\mathrm{Cu}$ in return flows from consolidation of sludge (co-settled sludge from primary treatment and biological trickling filters) and found that these contributed a significant fraction of the total $\mathrm{Cu}$ mass flows entering a primary settler. However, despite the increase of $\mathrm{Cu}$ concentrations, this return flow together with return of sludge from a trickling filter increased the removal of soluble $\mathrm{Cu}$ during primary settling due to increased suspended solids (SS) concentrations. In one of the plants sampled by Gourlay-Francé et al. [40], return liquors from sludge dewatering considerably increased both particle-bound and dissolved concentrations of $\mathrm{Cu}, \mathrm{Zn}$ and $\mathrm{Ni}$.

\subsection{Fractions of Dissolved Heavy Metals in Raw Wastewater}

Dissolved fractions of $\mathrm{Cu}, \mathrm{Cr}, \mathrm{Ni}, \mathrm{Pb}, \mathrm{Cd}, \mathrm{Zn}, \mathrm{Hg}$ and $\mathrm{Ag}$ in raw wastewater are given in Table 3. The fraction of dissolved heavy metals in raw wastewater varies according to different studies. With exception for $\mathrm{Ni}$, the ranges of the fractions of dissolved heavy metals are narrower when considering the studies known not to include return liquors (in the stream that was sampled). This indicates that return sludge liquors influence the heavy metal speciation; however, this conclusion should subject to a level of caution, since the amount of data is limited. $\mathrm{Ni}$ is often associated with the dissolved fraction to a higher degree than other heavy metals. 
Table 3. Fraction of dissolved heavy metals (\%, concentration of dissolved heavy metals in relation to total heavy metal concentrations) in influent wastewater.

\begin{tabular}{|c|c|c|c|c|c|c|c|c|c|}
\hline $\mathrm{Cu}$ & $\mathrm{Cr}$ & $\mathbf{N i}$ & $\mathbf{P b}$ & $\mathrm{Cd}$ & $\mathrm{Zn}$ & $\mathrm{Hg}$ & $\mathrm{Ag}$ & As & Reference \\
\hline 20 & 22 & 78 & 22 & 86 & - & - & - & - & {$[39]^{a, b}$} \\
\hline 14 & 86 & 59 & 6 & 100 & 12 & 40 & - & 67 & {$[46]^{\mathrm{c}}$} \\
\hline 24 & 24 & 57 & 18 & 23 & 25 & - & 15 & - & {$[33]^{d, b}$} \\
\hline 26 & - & 57 & 17 & 22 & 23 & 26 & - & - & {$[47]^{\mathrm{e}}$} \\
\hline 8 & 59 & 63 & 13 & 70 & 34 & $8 / 58$ & - & - & {$[42,43]^{\mathrm{a}, \mathrm{f}, \mathrm{b}}$} \\
\hline 10 & - & 33 & - & - & 18 & - & - & - & \\
\hline 14 & - & 56 & - & - & 27 & - & - & - & {$[40]^{a, g, b}$} \\
\hline 39 & - & 67 & 23 & - & 66 & - & - & - & {$[41]^{\mathrm{a}}$} \\
\hline 12 & 9 & 79 & 6 & 14 & 8 & - & - & - & {$[35]^{h, b}$} \\
\hline 4 & 9 & 70 & - & 6 & 75 & - & - & - & {$[29]^{\mathrm{i}}$} \\
\hline 55 & 7 & 67 & 5 & 8 & 24 & 9 & - & - & {$[48]^{\mathrm{C}}$} \\
\hline 16 & 21 & - & 70 & 36 & 12 & - & - & - & {$[34]^{a}$} \\
\hline $4-55$ & $7-86$ & $57-79$ & $5-70$ & $6-100$ & $8-75$ & $8-58$ & - & - & Range, all (11 studies) \\
\hline 8-39 & $21-59$ & $33-78$ & $13-70$ & $36-86$ & $12-66$ & $8-58$ & - & - & $\begin{array}{l}\text { Range for samples known to not include } \\
\text { return liquors ( } 5 \text { studies) }\end{array}$ \\
\hline
\end{tabular}

a Sampled before addition of return sludge liquors/directly when wastewater entered the plant. ${ }^{\mathrm{b}}$ The data were estimated from graph. ${ }^{c}$ The exact location of raw wastewater sampling is not clear. The sample might thus include return of liquor from sludge processing.

${ }^{d}$ Average of $\sim 20$ samples, sampled at nine different treatment plants. The data were estimated from graph. Details on sampling points for raw wastewater were not given in the reference, and therefore it is not known whether the sampled flow included return liquors. ${ }^{\mathrm{e}}$ Average from 16 WWTPs in the UK. Most samples of influent wastewater were taken before addition of return liquors. ${ }^{\mathrm{f}}$ A second sampling campaign performed $\sim 1.5$ yrs. later showed $58 \%$ dissolved $\mathrm{Hg}$ in influent wastewater. $\mathrm{g}$ Sampling was made at two different treatment plants. ${ }^{\mathrm{h}}$ Sampled after addition of return liquors from sludge digestion and after grit removal, but before return of another supernatant stream. In contrast to the other studies, the dissolved fraction was analyzed after filtering through a $0.2 \mu \mathrm{m}$ filter (instead of $0.45 \mu \mathrm{m}) .{ }^{i}$ Sampled after return of sludge from biological treatment and after grit removal. For Ni and $\mathrm{Zn}$, there was a suspicion that samples of dissolved heavy metals were contaminated to some extent, and it can be noted that compared to data from the other studies, these values are in the upper range.

\subsection{Correlation between Total Concentrations in Raw Wastewater and the Fraction of Dissolved Heavy Metals}

It is hypothesized that high total concentrations of heavy metals in wastewater coincide with high SS concentrations, and thus large complexation or sorption capacity of the solids in the wastewater, which could cause a lower fraction of dissolved heavy metals in raw wastewater. Nielsen and Hrudey (1983) demonstrated this trend; increased SS concentration decreased the concentration of dissolved heavy metals $(\mathrm{Ag}, \mathrm{Cd}, \mathrm{Cr}, \mathrm{Cu}$ and $\mathrm{Tl})$. To investigate this trend further, the correlations between total metal concentrations and fractions of dissolved heavy metals are investigated based on literature data, and are shown in Figure 1 . With respect to $\mathrm{Cu}, \mathrm{Ni}, \mathrm{Pb}$ and $\mathrm{Zn}$, the correlation is very weak or non-existent (based on $\overline{R^{2}} ; 0.02$ or less, as given in Figure 1). For $\mathrm{Cr}$ and $\mathrm{Cd}$, some correlation exists $\left(\overline{R^{2}}\right.$ of 0.24 and 0.11$)$. The correlation with respect to $\mathrm{Hg}$ appears to be stronger ( $\overline{R^{2}}$ of 0.97$)$; however, the negative correlation was broken when one of the references [47] was excluded, which indicates that the correlation is uncertain. 


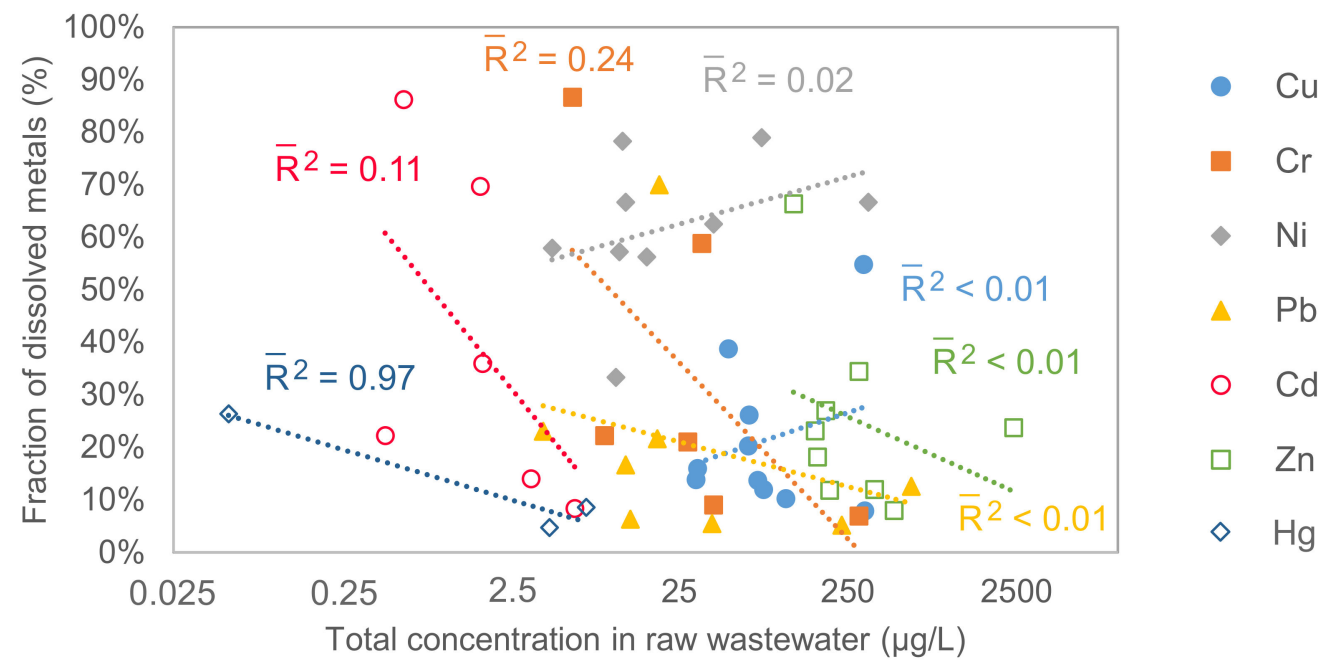

Figure 1. Fraction of dissolved heavy metals in raw municipal wastewater at different total heavy metal concentrations [34,35,39-44,46-48] ([40] includes data from two different WWTPs). (Data from [29,33] (included in Table 3) were not included, since average concentrations of total heavy metals in raw wastewater were not given/not easily read from paper.) (Data for As and Ag not available from multiple sites.) The dotted lines represent the linear regression between the percentage removal and the concentration of the different heavy metals in log form. The adjusted coefficient of determination $\left(\overline{R^{2}}\right)$ is given; this was calculated as follows: $1-\left(1-R^{2}\right)(n-1)(n-p-1)$, where $R^{2}$ is the coefficient of determination, $n$ is the number of data points for the respective metal and $p(=1)$ is the number of explanatory variables, excluding the constant.

\subsection{Fractions of Colloidal/Truly Dissolved or Inert/Labile Heavy Metals}

Hargreaves et al. [41] found that while around two-thirds of Ni and $\mathrm{Zn}$ in raw wastewater was associated with the dissolved fraction $(<0.45 \mu \mathrm{m})$, only $18 \%$ and $9 \%$, respectively, was found in the truly dissolved fraction. The truly dissolved fractions of $\mathrm{Cu}$ and $\mathrm{Pb}$ constituted similar shares of the total influent heavy metal concentrations (around 10\% and $5 \%$, respectively). In measurements at two different WWTPs in Paris with mixed domestic and industrial influents, Gourlay-Francé et al. [40] found no or very small amounts of $\mathrm{Cu}$ and $\mathrm{Zn}$ to be labile, while around half of the Ni was labile at one of the sites. $\mathrm{Cr}$ and $\mathrm{Pb}$ were present in the particulate fraction, but since the dissolved heavy metals were below the detection level, the fraction of labile $\mathrm{Cr}$ and $\mathrm{Pb}$ was not given. Buzier et al. [39] found around half the total influent concentration of $\mathrm{Ni}$ to be in the labile fraction. According to Buzier et al. [39], the fraction of labile heavy metals should constitute less than half the dissolved fraction of $\mathrm{Cd}, \mathrm{Cr}$ and $\mathrm{Pb}$; however, they did not quantify the labile fraction of these heavy metals, because the concentrations were below the detection level. Labile $\mathrm{Cu}$ constituted around a quarter of the dissolved heavy metals in influent wastewater.

Based on findings of Hargreaves et al. [41], the distribution of heavy metals between the particulate, colloidal and truly dissolved fraction was similar in the effluent from primary settling, as in raw wastewater. They therefore concluded that enhanced removal of colloidal matter could enable increased heavy metal removal. Chen et al. [49] found that particle-bound heavy metals in primary settler overflow were mainly associated with particle sizes of $44 \mu \mathrm{m}$ and smaller, which also indicates that increased removal of small particles could enhance removal of heavy metals. The organic matter in raw municipal wastewater is to a high extent found in the truly dissolved and colloidal phase; around $40-60 \%$ was found in these phases, according to a review by Modin et al. [50].

\section{Heavy Metal Removal Mechanisms}

During primary settling, heavy metals are removed by removal of solids with which the heavy metals are associated. Sorption/desorption of heavy metals in the primary settler together with the speciation or partitioning of heavy metals in the influent wastewater determine the removal capacity $[10,51]$. Heavy metal removal was shown to correlate 
positively with SS removal [52]. SS removal was measured frequently in the published literature (measured by [35,41,47]; measured but not reported by [39]; not measured by [46]; in [5], total solids was measured in influent and primary sludge). Buzier et al. [39] found a positive correlation between particulate concentrations of $\mathrm{Cu}$ and $\mathrm{Cr}$, and suspended solids concentrations, and proposed that "their removal is likely to be strongly linked to the suspended solids removal". Based on Gardner et al. [47], the SS removal in 16 WWTPs in the UK was in the range $\sim 45-63 \%$; however, the correlation between heavy metal removal and SS removal in each individual plant was not reported.

Removal through volatilization might occur to some extent for certain metals Yoshida et al. [5] reported probable volatilization of the heavy metal $\mathrm{Hg}(6 \%)$ and the semi-metal $\mathrm{Sb}(44 \%)$ during digestion of sludge.

Further factors of importance for removal of heavy metals include wastewater $\mathrm{pH}$ and hydraulic retention time (HRT) of the primary settler [51]. Increased HRT was shown to increase heavy metal removal [52]. Information on $\mathrm{pH}$ and HRT is not always available in the published literature (with respect to heavy metal removal during primary settling), which makes it hard to generalize the findings fully ( $\mathrm{pH}$ in influent and effluent from primary settling was reported by $[5,41]$, but not by $[35,39,46,47]$; HRT was not reported by $[5,35,39,41,46,47])$.

For optimization of the removal of both heavy metals and organic micropollutants during treatment of municipal wastewater, it was suggested that primary settlers should be optimized for heavy metal removal [53]. This is because removal of organic micropollutants in ASP is improved at longer HRT and solids retention time (SRT), while removal of heavy metals may be negatively influenced $[53,54]$.

Internal return flows and recirculation in WWTPs likely influence the heavy metal removal. Return flows from sludge dewatering (often to the primary settler) can affect the heavy metal removal $[10,54]$, and both increased and decreased removal were reported. Increased removal was hypothesized to be caused by increased concentration of SS (as mentioned above, removal of heavy metals was shown to correlate positively with SS removal), influence of residues of ferric chloride coagulants in the return liquors or changes in redox potential [10]. On the other hand, if the return liquors contain large amounts of heavy metals associated with fine particles (which do not settle easily), the total removal of heavy metals in the primary settler might decrease [10]. Ferric chloride residues could contribute to increased heavy metal removal by increasing the removal of particles in the primary treatment, or, hypothetically, the iron could replace heavy metal ions in EDTA complexes (so that the heavy metals could instead bind to particles) [10]. The exact influence of return flows on redox potential in the primary settler has yet to be examined, to our knowledge. Since the redox potential is expected to increase during municipal wastewater treatment [55], return flows will have higher redox potential than influent flows and could hypothetically have some influence on the redox potential in the primary settler, particularly if the return flows are large in volume. The wastewater redox potential influences the oxidation state of metals (depending on the standard reduction potential of each metal species), and of other compounds in the wastewater (which may cause formation of various metal compounds). Xiao et al. [56] investigated the removal of $\mathrm{Cu}$, $\mathrm{Pb}, \mathrm{Zn}$ and $\mathrm{Cr}$ in constructed wetlands treating municipal wastewater. They found that an increase of redox potential occurred during treatment ( $-163 \mathrm{mv}$ in the inflow and 184 $\mathrm{mV}$ in the outflow). They suggested that the reduction of sulphate $\left(\mathrm{SO}_{4}{ }^{2-}\right)$ to sulfide ( $\left.\mathrm{S}^{2-}\right)$ (occurring under reducing conditions/low redox values), followed by formation of heavy metal sulfides, played an important role for the distribution of $\mathrm{Cu}, \mathrm{Pb}$, and $\mathrm{Zn}$ during treatment. In the case of $\mathrm{Cr}$, increases in redox potential may cause conversion of $\mathrm{Cr}$ (III) into $\mathrm{Cr}(\mathrm{VI})$, which is a more mobile species [56].

Biodegradation is not directly relevant when it comes to heavy metals, though heavy metals could be physically entrapped by biomass (if insoluble), adsorbed to bacterial walls and extracellular polymers or actively taken up by bacteria (if in dissolved state), which means that biological treatment has some effect on heavy metals [10]. In plant layouts 
where sludge from ASP/BNR is returned to the primary settler (and not directly to the head of the ASP/BNR), adsorption to or uptake by biomass influences heavy metal removal capacity in the primary settler. According to [25], heavy metals could attach to lipids, proteins and polysaccharides at cell surfaces by sorption to carboxyl, hydroxyl, phosphate and sulfonate groups. Extracellular polymeric substances (EPS) were stated to have a high importance in the entrapment/adsorption of micropollutants by bacterial cells [10], and sorption to EPS was shown to be $\mathrm{pH}$-dependent [57] with different sorption capacity for different heavy metals [58].

Process chemicals may contain trace heavy metals which cause significant increases in heavy metal concentrations in wastewater. Buzier et al. [39] found that addition of $\mathrm{FeCl}_{3}$ during tertiary treatment added significant amounts of $\mathrm{Cr}, \mathrm{Co}, \mathrm{Cu}$ and $\mathrm{Ni}$ (which may also enter the primary settler with the return flows).

\section{Partitioning Constants and Modeling of Heavy Metal Speciation and Removal}

The tendency for heavy metals to occur in the particulate and dissolved phase can be described by the solid/liquid or water/sludge partitioning constant, often referred to as $K_{P}$ or $K_{D}[40,54]$. Gourlay-Francé et al. [40] found that the solid/liquid partitioning constant of heavy metals varied along the treatment process, and no relation was found between $\mathrm{K}_{\mathrm{D}}$ and SS or dissolved organic carbon (DOC) concentrations. Similarly, in the model TOXCHEM (described by Parker et al. [59]), the partitioning constant is assumed to take different values in primary clarification compared to in ASP/BNR. According to Wang et al. [60], dissolved organic matter (measured as chemical oxygen demand (COD) in supernatant after sample centrifugation) significantly affects heavy metal partitioning in influent wastewater, but this effect could be disregarded at neutral or low $\mathrm{pH}(<8)$. A model for the prediction of heavy metal partitioning between dissolved and particulate fractions was suggested, where heavy metal partitioning is dependent on $\mathrm{pH}$ and SS concentration. Measurements by Katsoyiannis and Samara [61] revealed a negative correlation between $\log K_{D}$ and DOC concentrations, indicating that a higher DOC concentration could result in higher amount of heavy metals in the dissolved fraction and thus a lower heavy metal removal in primary settling. Findings by Gourlay-Francé et al. [40] were contradictory to the findings by Wang et al. [60] and Katsoyiannis and Samara [61]. They calculated a constant for partitioning between labile and inert fractions of dissolved heavy metals and called this partitioning constant $\mathrm{K}_{\mathrm{DOC}}$. They found that $\mathrm{K}_{\mathrm{DOC}}$ was highly variable between different sites in the treatment plant, and thus hypothesized that sorption to DOC may not control heavy metal speciation, or that equilibrium may not be reached due to fast degradation of organic matter. However, another interpretation of their findings could be that varying composition and complexing capacity of DOC in different treatment steps caused the variability in $\mathrm{K}_{\mathrm{DOC}}$. Dionisi et al. [54] modelled removal of $\mathrm{Cd}$ and $\mathrm{Pb}$ in a sequencing batch reactor (a type of ASP), and calibrated $K_{P}$ based on experimental data. They did not include the organic matter concentration as a variable when they calibrated the $\mathrm{K}_{\mathrm{P}}$ value. However, they found that the concentration of biodegradable COD in the influent wastewater together with the specific rate of endogenous metabolism of the biomass had an indirect effect on the heavy metal removal capacity, since they determined the amount of biomass in the process.

When modelling heavy metal removal in full-scale treatment plants, an "aqueous compartment" and a "solid phase" has generally been considered, where heavy metals in the "aqueous compartment" are dissolved, and heavy metals in the "solid phase" are attached to sludge [51]. In models, the removal of heavy metals in the "solid phase" depends upon the removal of SS achieved. The dissolved heavy metals will end up in the effluent if they are not sorbed during the treatment process. Cecchini et al. [46] found that the concentration of dissolved heavy metals in effluents from primary settling followed by ASP was similar to the concentrations in raw wastewater. This indicates that dissolved heavy metals were relatively unaffected during the process, or that sorption and desorption balanced out over the treatment process as a whole. In either case, for this treatment plant, 
the heavy metals which were not removed during primary settling chiefly ended up in the effluent. Barret et al. [62] suggested a "three compartment-model" for sorption of micropollutants (not heavy metals) to sludge; sorption to particles (analyzed in centrifugation cake) associated with dissolved and colloidal matter (analyzed in centrifugation supernatant filtered at $1.2 \mu \mathrm{m}$ ) and freely dissolved (not measured experimentally). A three-compartment model might increase understanding of the heavy metal fate during physical separation and requires that the full-scale physical model incorporates dynamics of colloidal particles.

Cloutier et al. [63] modelled the removal of particulate heavy metals during primary settling under the assumption that removal of particle-bound heavy metals is relative to the removal of SS in the settler (removal efficiency thus being the same for all heavy metals). The model also assumes that dissolved heavy metals are removed only by mass flow of dissolved heavy metals with sludge, i.e., the concentration of dissolved heavy metals in primary settler overflow is the same as in primary settler influent. These model assumptions do not agree with the data according to, e.g., Karvelas et al. [35]. They found an SS removal of $51 \%$, while the removal of different particle-bound heavy metals was between $22-81 \%$, which indicates that sorption/desorption may occur during primary settling.

\section{Technologies for Enhanced Heavy Metal Removal}

Enhanced heavy metal removal during primary settling may target dissolved or particle-bound heavy metals. Technologies used for heavy metal removal from wastewaters include chemical precipitation, ion-exchange, adsorption, coagulation/flocculation, electrodialysis, membrane filtration, photocatalysis and electro-chemical treatment technologies [64-66]. These were mainly applied to wastewaters of industrial origin from production of, e.g., paper, pesticides, leather (tanneries), metal objects (plating) and ore (mining) [65]. Some features of these heavy metal removal technologies are summarized in Table 4. Due to large amounts of fibers in municipal wastewater, technologies which involve filtration, e.g., membrane filtration, were presumed not to be relevant for treatment during or directly following primary settling (as fouling may be an issue).

By introducing enhanced removal targeting both dissolved and particle-bound heavy metals, the heavy metal removal during primary settling could theoretically approach $100 \%$. However, in addition to the heavy metal removal capacity of the different technologies, the following conditions are also of relevance for the enhanced removal of heavy metals from municipal wastewater during primary settling:

- Should be suitable for wastewater with high solids/organic matter concentration.

- Low impact in terms of energy use and sludge production.

- Low removal of phosphorus $(\mathrm{P})$ and organic matter. 
Table 4. Features of heavy metal removal technologies.

\begin{tabular}{|c|c|c|c|c|c|c|c|}
\hline Method & $\begin{array}{c}\text { Heavy Metal } \\
\text { Removal Capacity }\end{array}$ & $\begin{array}{l}\text { Efficiency at High Solids/ } \\
\text { Organic Matter } \\
\text { Concentration }\end{array}$ & $\begin{array}{l}\text { Selectivity for } \\
\text { Heavy Metals }\end{array}$ & Cost & Operation & By-Products & Ref. \\
\hline Adsorption & $\begin{array}{c}\text { Wide range, } \\
\text { maximum sorption } \\
\text { capacity } \\
\text { depends on the type } \\
\text { of sorbent. }\end{array}$ & $\begin{array}{c}\text { Not directly affected by } \\
\text { solids concentration, though } \\
\text { the } \\
\text { interaction of heavy metals } \\
\text { and dissolved organic matter } \\
\text { may } \\
\text { influence heavy metal } \\
\text { sorption. }\end{array}$ & $\begin{array}{l}\text { Efficiency for } \\
\text { different heavy } \\
\text { metals depends on } \\
\text { sorbent properties. }\end{array}$ & $\begin{array}{l}\text { Low-cost (if using } \\
\text { low-cost sorbents). } \\
\text { However, many } \\
\text { sorbents have so far } \\
\text { only been tested in } \\
\text { lab-scale. }\end{array}$ & $\begin{array}{l}\text { Simple operation } \\
\text { (wide pH-range). } \\
\text { Separation of sorbent } \\
\text { may be a } \\
\text { challenge. }\end{array}$ & $\begin{array}{c}\text { Less sludge } \\
\text { production. } \\
\text { Waste sorbents } \\
\text { (if not regenerated). }\end{array}$ & {$[60,64-68]$} \\
\hline $\begin{array}{c}\text { Electrochemical }(\mathrm{EC}) \\
\text { treatment } \\
\text { technologies }\end{array}$ & $\begin{array}{c}\text { Efficient heavy metal } \\
\text { removal. }\end{array}$ & $\begin{array}{c}\text { Electroflotation separates } \\
\text { heavy metals and organic } \\
\text { matter. } \\
\text { Some electrochemical } \\
\text { methods simultaneously } \\
\text { decompose } \\
\text { organic matter. }\end{array}$ & $\begin{array}{c}\text { Heavy metal removal } \\
\text { or } \\
\text { deposition possible, } \\
\text { but not } \\
\text { selective for heavy } \\
\text { metals } \\
\text { (different EC } \\
\text { treatment } \\
\text { generates } \\
\text { agglomeration/ } \\
\text { floccula- } \\
\text { tion/precipitation } \\
\text { etc.) }\end{array}$ & $\begin{array}{l}\text { Low chemical usage. } \\
\text { Initial investment } \\
\text { cost is high. High } \\
\text { electricity } \\
\text { costs-proportional } \\
\text { to the volume of } \\
\text { water. Frequent } \\
\text { replacement of } \\
\text { electrodes. }\end{array}$ & $\begin{array}{l}\text { Easy to operate. } \\
\text { Corrosion may be a } \\
\text { problem. Quick } \\
\text { adaptation to } \\
\text { fluctuating flow and } \\
\text { pollutant } \\
\text { concentration. }\end{array}$ & $\begin{array}{l}\text { Less sludge } \\
\text { production. } \\
\text { No secondary } \\
\text { pollution. }\end{array}$ & {$[64-66,69]$} \\
\hline $\begin{array}{l}\text { Coagulation/ } \\
\text { flocculation }^{\text {a }}\end{array}$ & $\begin{array}{l}\text { Cannot remove } \\
\text { heavy metals } \\
\text { completely. }\end{array}$ & $\begin{array}{l}\text { Should work well when the } \\
\text { heavy metals are associated } \\
\text { with colloids. Will } \\
\text { simultaneously } \\
\text { remove larger amounts of } \\
\text { solids. }\end{array}$ & $\begin{array}{c}\text { Not selective for } \\
\text { heavy metals, but } \\
\text { enhanced flocculants } \\
\text { (e.g., with chitosan) } \\
\text { have shown } \\
\text { increased heavy } \\
\text { metal removal } \\
\text { efficiencies, as has } \\
\text { e.g., } \\
\text { flocculation after } \\
\text { binding heavy metals } \\
\text { to humic acids. }\end{array}$ & $\begin{array}{c}\text { Cost effective, } \\
\text { though chemical } \\
\text { consumption is high. }\end{array}$ & $\begin{array}{c}\text { Simple operation, } \\
\text { requires } \\
\text { coagulant/flocculant } \\
\text { chemicals. }\end{array}$ & $\begin{array}{c}\text { Increased sludge } \\
\text { volume, though good } \\
\text { dewaterability. }\end{array}$ & {$[64,65]$} \\
\hline
\end{tabular}


Table 4. Cont.

\begin{tabular}{|c|c|c|c|c|c|c|c|}
\hline Method & $\begin{array}{c}\text { Heavy Metal } \\
\text { Removal Capacity }\end{array}$ & $\begin{array}{l}\text { Efficiency at High Solids/ } \\
\text { Organic Matter } \\
\text { Concentration }\end{array}$ & $\begin{array}{l}\text { Selectivity for } \\
\text { Heavy Metals }\end{array}$ & Cost & Operation & By-Products & Ref. \\
\hline Ion-exchange & $\begin{array}{l}\text { Synthetic resins can } \\
\text { remove nearly all } \\
\text { heavy metals from } \\
\text { solution. }\end{array}$ & $\begin{array}{c}\text { Easily fouled by organics } \\
\text { and other solids in the } \\
\text { wastewater. }\end{array}$ & $\begin{array}{c}\text { Non- } \\
\text { selective/Removes } \\
\text { only limited heavy } \\
\text { metal ions. More } \\
\text { effective for heavy } \\
\text { metals with high } \\
\text { ionic charge. }\end{array}$ & $\begin{array}{l}\text { Operational cost is } \\
\text { high, which makes it } \\
\text { expensive especially } \\
\text { at low heavy metal } \\
\text { concentrations. }\end{array}$ & Sensitive to $\mathrm{pH}$. & $\begin{array}{l}\text { Resin regeneration } \\
\text { may cause secondary } \\
\text { pollution. }\end{array}$ & [64-66] \\
\hline $\begin{array}{l}\text { Chemical } \\
\text { precipitation }^{\text {a }}\end{array}$ & $\begin{array}{l}\text { Not effective at low } \\
\text { heavy metal } \\
\text { concentration. }\end{array}$ & $\begin{array}{l}\text { Can give high removal of } \\
\text { COD. }\end{array}$ & $\begin{array}{c}\text { Complexing agents } \\
\text { inhibit } \\
\text { hydroxide } \\
\text { precipitation. } \\
\text { For hydroxide } \\
\text { precipitation, optimal } \\
\text { pH differs depending } \\
\text { on heavy metal while } \\
\text { sulfide precipitation } \\
\text { gives high degree of } \\
\text { heavy metal removal } \\
\text { over a broad pH } \\
\text { range. }\end{array}$ & $\begin{array}{l}\text { Low capital cost, } \\
\text { additional cost for } \\
\text { sludge disposal } \\
\text { which can make it } \\
\text { less economically } \\
\text { attractive. }\end{array}$ & $\begin{array}{l}\text { Simple operation, } \\
\text { requires large } \\
\text { amount of } \\
\text { precipitation } \\
\text { chemicals. } \\
\text { Metal sulfides may } \\
\text { form colloidal } \\
\text { precipitates that } \\
\text { cause settling } \\
\text { problems. }\end{array}$ & $\begin{array}{l}\text { Large volumes of low } \\
\text { density sludge. } \\
\text { Sludge from sulfide } \\
\text { precipitation has } \\
\text { better thickening and } \\
\text { dewatering } \\
\text { properties compared } \\
\text { to hydroxide } \\
\text { precipitation. } \\
\text { Hydrogen sulfide } \\
\text { formation may be an } \\
\text { issue. }\end{array}$ & {$[64-66]$} \\
\hline Photocatalysis & $\begin{array}{l}\text { May be operated at } \\
\text { trace concentrations } \\
\text { (less than ppm). }\end{array}$ & $\begin{array}{l}\text { Guo et al. [70] investigated } \\
\mathrm{Cd}^{2+} \text { and } \mathrm{Pb}^{2+} \text { removal } \\
\text { using Gamma irradiation } \\
\text { technique (which works in a } \\
\text { similar principle as } \\
\text { photocatalysis) and found } \\
\text { decreased removal at } \\
\text { increasing organic matter } \\
\text { concentration. }\end{array}$ & $\begin{array}{l}\text { Organic pollutants } \\
\text { and heavy metals are } \\
\text { removed } \\
\text { simultaneously, } \\
\text { oxidation and } \\
\text { reduction } \\
\text { mechanisms are } \\
\text { non-selective. } \\
\text { Cationic heavy } \\
\text { metals may be } \\
\text { reduced to less toxic } \\
\text { forms and/or } \\
\text { deposited in the } \\
\text { process. }\end{array}$ & - & Long retention time. & $\begin{array}{l}\text { Less harmful } \\
\text { byproducts. }\end{array}$ & {$[65,66,70]$} \\
\hline
\end{tabular}


The removal of $\mathrm{P}$ and organic matter when enhanced heavy metal removal is introduced is of relevance because (i) the reuse of secondary sludge is more attractive if the organic matter and P content is high, and (ii) certain amounts of COD and P are required for the "treatability" of primary settler effluent in ASP/BNR. Treatability requirements are as follows: for conversion of $1 \mathrm{mg}$ of nitrogen in APS/BNR, $2.9 \mathrm{mg}$ of COD is theoretically required, while to fulfill criteria of less than $10 \mathrm{mg}$ nitrogen in the effluent in full scale BNR, a required ratio of 4.7-8.7 was reported [71]; a general rule to determine the P requirement for heterotrophic growth of biomass is to multiply the COD concentration in primary effluent with 0.005 [71].

Among the treatment technologies described in Table 4, some may have limited potential in relation to the additional requirements. Precipitation may not be efficient when the heavy metal concentrations are low due to large consumption of chemicals and large production of sludge. The ion exchange process is not appropriate for primary treatment of municipal wastewater since it is prone to fouling. Electrochemical treatment methods suffer from high electricity requirements when wastewater volumes are large and may be more appropriate for decentralized wastewater treatment operations. With respect to photocatalysis, there is limited experience with full-scale operation for treatment of municipal wastewater. Loeb et al. [72] pointed out that this may be due to the complexity of large-scale photocatalysis systems. The most attractive methods for enhanced heavy metal removal in this application are thus coagulation/flocculation and adsorption. Coagulation/flocculation could mainly increase the removal of particle-bound heavy metals and heavy metals associated with colloidal matter. However, removal of dissolved heavy metals could be enhanced by use of modified flocculation agents. Addition of a sorbent during or directly following primary treatment could enhance mainly the removal of dissolved heavy metals. Coagulation/flocculation was previously investigated by, e.g., Hargreaves et al. [73,74], while addition of low-cost solid sorbents during primary treatment of municipal wastewater was not previously examined, to our knowledge. Both sorption and coagulation/flocculation are considered easy to operate and relatively costeffective technologies.

Though not examined in detail here, it is also of importance to consider how enhanced heavy metal removal during primary treatment could affect the removal of heavy metals during secondary treatment and fate of heavy metals during sludge treatment. High removal of BOD during primary treatment may decrease the complexation of heavy metals during secondary treatment [10], which affects the effluent quality. Sludge dewatering may influence both the sludge quality and the amounts of heavy metals entering primary settling (through return liquors, as previously mentioned). Data according to Yoshida et al. [5] indicated that P-loss from sludge during dewatering was greater than loss of heavy metals. In the plant which they examined, sludge dewatering thus had a negative impact on the sludge quality, while heavy metal loss from sludge contributed significantly to the total influent heavy metal load (5-12\%). In the case of enhanced heavy metal removal during primary treatment, the primary sludge will contain larger amounts of heavy metals, while secondary sludge will likely contain smaller amounts of heavy metals (depending on the partitioning of heavy metals between secondary sludge and effluent), which may affect the heavy metal losses / fate during sludge dewatering.

\subsection{Adsorption Using Low-Cost Sorbents}

Low-cost sorbents can be produced from many different materials. The lower cost of such sorbents compared to traditional sorbents is associated with availability-being abundant in nature or produced as a byproduct or waste from other activities/industries. A low-cost sorbent should also require no or limited preprocessing before use, though preprocessing that significantly increases the sorption capacity may be motivated [75]. Low-cost sorbents include:

- Natural materials such as zeolite and clay [75]. 
- Waste materials such as agricultural residues/plant residues and industrial by-products $[76,77]$ including sewage sludge in wet or dried state [78]. Such waste materials were also referred to as biosorbents when applied as sorbents. Biosorbents are living or dead microorganism biomass (e.g., bacteria, microalgal and fungal biomass) $[79,80]$, or derived from different lignocellulosic materials such as bark, husks, shells, etc. [81].

- Biochars. Production of low-cost biochar use of various organic wastes/residues were investigated, such as saw dust, rice husks, municipal waste, manure, sewage sludge, etc. [82].

Relative sorption capacity (\% removal) can generally be expected to increase at low initial metal concentration. Removal of $\mathrm{Cd}, \mathrm{Cr}, \mathrm{Cu}, \mathrm{Pb}, \mathrm{Zn}, \mathrm{Hg}$ and $\mathrm{Ag}$ may approach $100 \%$ when the initial heavy metal concentration is low [83]. Low concentrations of metals thus facilitate the use of low-cost sorbents with no or little preprocessing (the sorption capacity does not need to be maximized to achieve high removal percentage). Possible challenges of low-cost sorbents are to achieve stable sorption performance (since the properties of waste materials may vary over time) and to separate the sorbent from solution (some sorbents form small, low-density particles) [79,80].

The concurrent removal of COD and $\mathrm{P}$ by addition of low-cost sorbents is expected to be relatively small. Utilization of biochars for $\mathrm{P}$ removal has generally considered modification of the biochar with metal salts to enhance phosphate sorption capacity $\left(\mathrm{FeCl}_{3}\right.$, $\mathrm{MgCl}_{2}$ ) [84]. Peng et al. [85] found that phosphate was not sorbed but released from unmodified sludge-derived biochar. Alkaline sorbents are generally considered appropriate for heavy metal sorption since this is promoted by increased $\mathrm{pH}$, and sorption of phosphate is less efficient at high $\mathrm{pH}$ [85].

\subsection{Coagulation/Flocculation}

Coagulation/flocculation is widely used in WWTPs in association with primary settling (for increasing solids and $\mathrm{P}$ removal) and in simultaneous precipitation (to enhance $\mathrm{P}$ removal in ASP); it is also used as a tertiary treatment step (for P removal) [86]. Coagulation refers to charge neutralization of colloids followed by agglomeration, while flocculation occurs when small particles are joined together through physical bonds-both resulting in formation of larger particles which can be removed through sedimentation. Aluminum, iron and calcium salts are commonly-used coagulants, while polyaluminium chloride, polyacrylamide and polyferric sulphate are commonly-used flocculants $[64,86]$.

Johnson et al. [87] showed that removal of heavy metals $(\mathrm{Cr}, \mathrm{Cu}, \mathrm{Pb}, \mathrm{Ni}$, and $\mathrm{Zn})$ in primary treatment could be more than doubled by adding a coagulant $\left(\mathrm{FeCl}_{3}\right)$ and an anionic polymer (SS removal increased from $68 \%$ to $82 \%$, indicating that the removal of colloidal and dissolved metals also increased). More than $90 \%$ removal of $\mathrm{Pb}, \mathrm{Cu}$ and $\mathrm{Zn}$ was shown using commercial aluminum salt coagulants for treatment of combined sewer overflow [88]. One of the possible mechanisms for removal of heavy metals was suggested to be sorption to aluminum oxyhydroxide mineral phases. The concurrent removal of SS was very high. The COD and $P$ removal was not examined, but typical COD removal was reported to be around $60 \%$, which may lead to an insufficient $\mathrm{C} / \mathrm{N}$ ratio for ASP/BNR. Chemically-enhanced microsieving (as a replacement for primary settling) resulted in a $\mathrm{C} / \mathrm{N}$ ratio and $\mathrm{P}$ concentrations lower than those required for ASP/BNR (at $>80 \%$ SS removal) [71]. In this context, complete removal of solids (particle-bound heavy metals) is generally not an option when conventional primary settling and ASP/BNR is applied. The typical SS removal during conventional primary settling is $\sim 60 \%$ [89].

Increased heavy metal removal in coagulation/flocculation systems is possible through use of polymeric supports, which were impregnated with nanoparticles having high heavy metal affinity. Such flocculation agents include chelating polymers and polymers impregnated with metal hydroxides (e.g., $\mathrm{Fe}(\mathrm{III}), \mathrm{Mn}(\mathrm{IV})$ ) [90]. The following are examples of flocculation agents with improved heavy metal removal capacity: 
- Polymers in the form of EPS are naturally produced by bacteria. These contain functional groups such as carboxyl, hydroxyl, amino and phosphate groups, which are involved in the removal of heavy metals [91]. Polymers generated by bacteria have also been referred to as bioflocculants. Bioflocculants, which are currently under development, showed a high capacity for heavy metal removal, e.g., for $\mathrm{Cd}, \mathrm{Cu}, \mathrm{Hg}$ and $\mathrm{Zn} \mathrm{[91].} \mathrm{Liu} \mathrm{et} \mathrm{al.} \mathrm{[92]} \mathrm{found} \mathrm{that} \mathrm{EPS} \mathrm{extracted} \mathrm{from} \mathrm{activated} \mathrm{sludge} \mathrm{could}$ remove $37-99 \%$ of heavy metals (removal increased in the order: $\mathrm{Ni}<\mathrm{Co}<\mathrm{Cd}<\mathrm{Cr}<$ $\mathrm{Cu}<\mathrm{Zn}$ ) at a heavy metal concentration range of $10-100 \mathrm{mg} / \mathrm{L}$.

- Heavy metal sorption capacity of polymers may be increased through impregnation of polymers with chelating groups [90]. One such example is the application of the natural material Chitosan, which was shown to remove $\mathrm{Cu}, \mathrm{Cr}$ and $\mathrm{Ni}$ efficiently in lab scale flocculation experiments [93].

- Hargreaves et al. [73] investigated heavy metal removal from municipal wastewater effluent (after treatment in a trickling filter) by addition of ferric chloride ( $\mathrm{FeCl} 3)$, polyethyleneimine (synthetic polymer), chitosan and floculan (biopolymers). Floculan (a tannin-containing, modified plant-based material) performed removal of $77 \% \mathrm{Cu}$, $68 \% \mathrm{~Pb}$ and $42 \% \mathrm{Zn}$, while efficient $\mathrm{Ni}$ removal was not achieved. $\mathrm{FeCl}_{3}$ (which is commonly used in conventional municipal wastewater treatment) achieved similar removal of $\mathrm{Cu}, \mathrm{Pb}$ and $\mathrm{Zn}$. The drawback of $\mathrm{FeCl}_{3}$ application is that it contains $\mathrm{Ni}$, which may lead to increased $\mathrm{Ni}$ concentrations in treated wastewater. It also removes considerable amounts of $\mathrm{P}$ (while $\mathrm{P}$ removal by floculan was negligible). COD removal of both $\mathrm{FeCl}_{3}$ and floculan was less than $50 \%$. Floculan is a commercially available product, though a drawback is that it has a higher cost compared to $\mathrm{FeCl}_{3}$.

\section{Current and Potential Heavy Metal Separation during Primary Settlement}

Literature data on the potential removal of total heavy metal concentrations in primary settlers are summarized in Table 5. The removal efficiency is in many cases reported to be highest for $\mathrm{Pb}$, while the lowest removal is often found for $\mathrm{Ni}$, although the variation is large.

In most cases, the sampling of influent was made before addition of return sludge liquors, or it is unclear exactly at what point the influent was sampled, so the removal during primary settling according to Table 5 may not be fully representative of the actual removal capacity in primary settlers. Considering data from Goldstone et al. [42-44], who sampled the influent both before and after addition of return sludge liquors, it is evident that the calculated removal efficiency is larger for all heavy metals if the influent concentrations after addition of return sludge liquors are considered. This is because the return sludge liquors generally have a higher heavy metal concentration than the influent (according to Brown et al. [23], 10-300 times higher) and thus add heavy metals to the primary settler influent.

Brown et al. [23] found that the percentage of heavy metal removal during primary settling was proportional to the total heavy metal concentration in the influent. Collected data from six studies (Figure 2) show that there was a general trend (though not very strong; $\overline{R^{2}} \leq 0.21$ ) that increased fractions of particulate heavy metals in raw wastewater can increase the total heavy metal removal during primary settling. This trend could not be shown for $\mathrm{Cr}$ and $\mathrm{Pb}$. Since these heavy metals were mainly found in the particulate fraction in all underlying studies, the considerably large variation in removal efficiency might have had other causes than the heavy metal speciation (such as the settler loading/ HRT). It should be noted that the total removal efficiencies are uncertain since the influent sampling was often made before addition of return liquors, or the exact sampling point is not known for the underlying studies. 
Table 5. Removal of heavy metals during primary settling (\%) (data for As not available).

\begin{tabular}{|c|c|c|c|c|c|c|c|c|c|c|}
\hline $\mathrm{Cu}$ & $\mathrm{Cr}$ & $\mathrm{Ni}$ & $\mathbf{P b}$ & $\mathrm{Cd}$ & $\mathrm{Zn}$ & $\mathrm{Hg}$ & Ag & $\begin{array}{c}\text { Removal Based on } \\
\text { Concentration/Mass } \\
\text { Flow/Not Specified } \\
\text { (C/M/n.s.) }\end{array}$ & $\begin{array}{c}\text { Sampling Made Prior } \\
\text { To/After Return } \\
\text { Liquors/Not Specified } \\
\text { (P/A/n.s.) }\end{array}$ & Reference \\
\hline 9 & 2,4 & 2.5 & - & - & 14 & - & - & M & - & {$[22]^{\mathrm{a}}$} \\
\hline $12-70$ & $17-36$ & - & $28-67$ & $0-25$ & $22-68$ & $13-54$ & - & C & n.s. & {$[23]^{\mathrm{b}}$} \\
\hline 44 & 59 & 29 & 74 & 33 & - & - & - & $\mathrm{C}$ & $\mathrm{P}$ & {$[39]^{c}$} \\
\hline 23 & 17 & 2 & 54 & 14 & 19 & - & - & M & n.s. & [26] \\
\hline 59 & 60 & 67 & 71 & 67 & 73 & 75 & - & n.s. & A & [42-44] \\
\hline 39 & 55 & 43 & 50 & 41 & 64 & 62 & - & n.s. & $P$ & [42-44] \\
\hline 22 & - & 22 & 23 & - & 20 & 52 & - & C & $P$ & {$[41,94]$} \\
\hline 29 & 39 & 24 & 23 & 32 & 22 & - & - & M & $\mathrm{P}^{\mathrm{d}}$ & {$[35]^{\mathrm{c}}$} \\
\hline 70 & 73 & 23 & 73 & 72 & 74 & - & - & C & $\mathrm{P}$ & {$[27,28]$} \\
\hline 60 & 68 & 50 & - & 39 & 44 & - & - & M & $P^{d}$ & [29] \\
\hline 32 & 55 & 15 & 61 & 50 & 53 & 57 & - & C & n.s. & [48] \\
\hline 61 & 47 & 22 & 65 & 68 & 60 & 61 & 43 & M & A & {$[5]^{c, e}$} \\
\hline 31 & - & 8 & 31 & 33 & 39 & 54 & - & C & $P^{f}$ & {$[47]^{\mathrm{c}}$} \\
\hline $12-70$ & $17-73$ & $2-67$ & $23-74$ & $0-72$ & $20-74$ & $13-75$ & - & & & Range $\mathrm{g}$ \\
\hline
\end{tabular}

${ }^{a}$ Data from pilot plant experiments at influent heavy metal concentrations $>10 \mathrm{mg} / \mathrm{L}$. Removal was calculated based on amount of heavy metals in primary sludge (not in primary settler effluent). No return liquors were added in the pilot plant. ${ }^{\mathrm{b}}$ Range of four different treatment plants. ${ }^{\mathrm{c}}$ The data were estimated from graph. ${ }^{\mathrm{d}}$ Influent wastewater was sampled after addition of return sludge liquors and after grit removal, but before return of another supernatant stream. ${ }^{e}$ Removal was calculated based on distribution of heavy metals between effluent, primary sludge and secondary sludge, i.e., mass flows. This is comparable to sampling the influent after addition of return sludge liquors. ${ }^{\mathrm{f}}$ Average from 16 WWTPs. Most samples of influent wastewater were taken before addition of return sludge liquors. g Data from Barth et al. [22] were not included, since the study was conducted with metal spiking of influent.

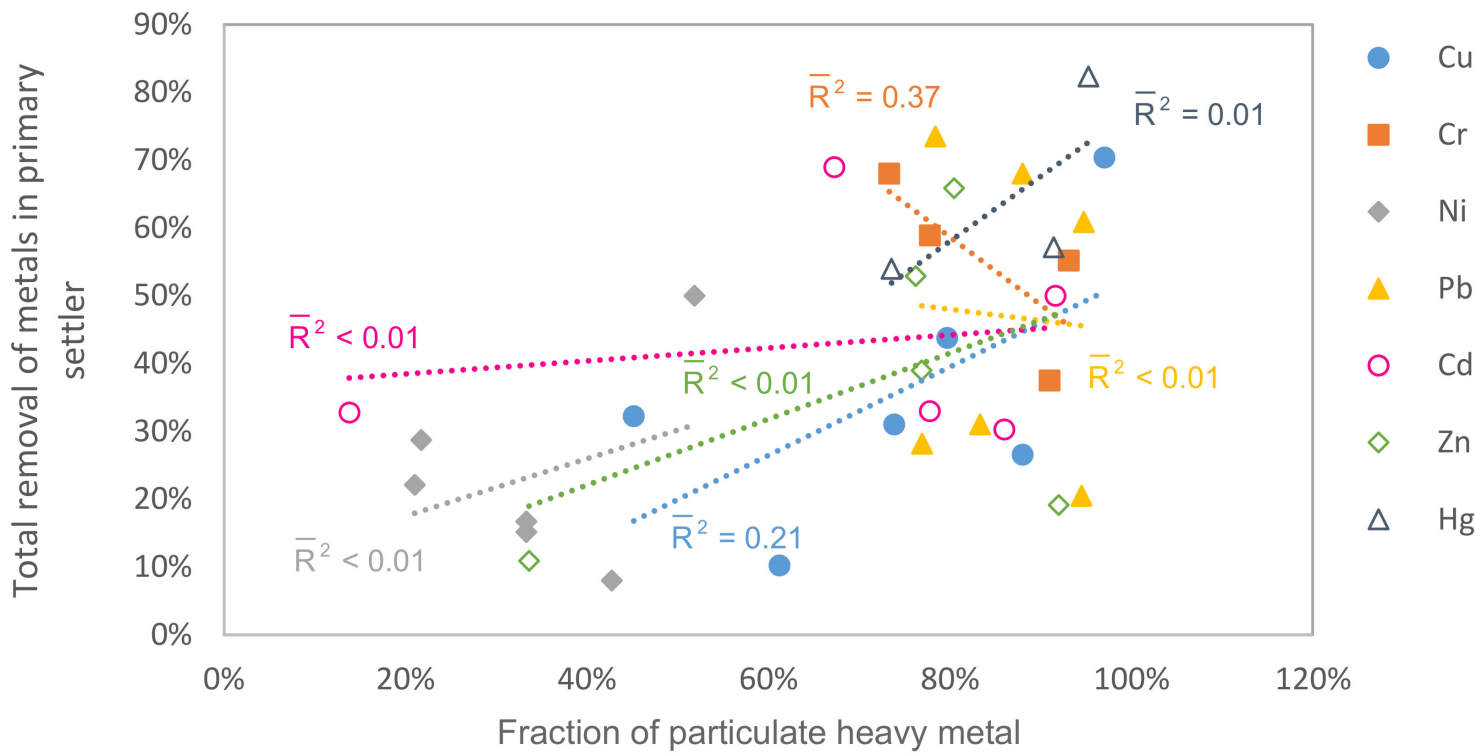

Figure 2. Total removal of heavy metals in primary settler at different fractions of particulate heavy metals in raw wastewater. [35,39,41-44,47,48]. (Data for As and Ag not available.) The dotted lines represent the linear regression between the fraction of particulate heavy metals in raw wastewater and total removal of heavy metals in the primary settler, and strength of correlation is indicated with $\overline{R^{2}}$ values.

The total removal of heavy metals in the primary settler varied greatly between studies and seemed to increase somewhat at higher fractions of particulate heavy metals in raw wastewater. Nevertheless, the primary settler effluent concentrations correlated with the concentrations in raw wastewater; see Figure 3. A similar correlation was found by Santos and Judd [95] for the removal of heavy metals in ASP and membrane bioreactors. 


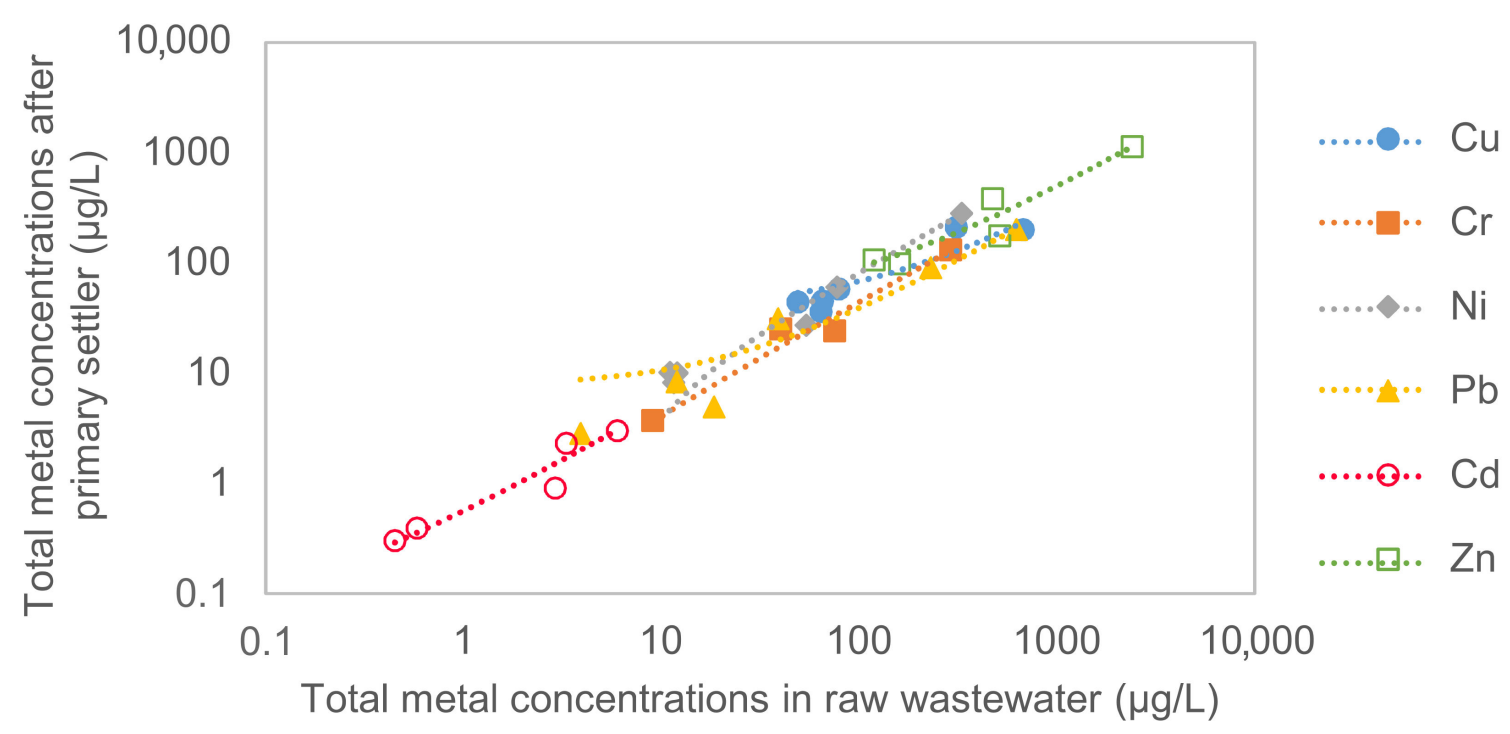

Figure 3. Total heavy metal concentrations after primary settling compared to total heavy metal concentrations in raw wastewater. [35,39,41-44,47,48]. (Sufficient data for As, Ag and Hg not available.) The dotted lines represent the linear regression between the total heavy metals concentrations in raw wastewater and total heavy metal concentrations after primary settling ( $\mathrm{R}^{2}$ values: $0.75,0.99,>0.99,0.99,0.88$ and 0.97 for $\mathrm{Cu}, \mathrm{Cr}, \mathrm{Ni}, \mathrm{Pb}, \mathrm{Cd}$ and $\mathrm{Zn}$, respectively; linear relations between concentration in raw wastewater $(\mathrm{x})$ and concentration after primary settler $(\mathrm{y}): y_{\mathrm{Cu}}=0.29 x_{\mathrm{Cu}}+39$, $y_{C r}=0.45 x_{C r}-0.42, y_{N i}=0.86 x_{N i}-4.9, y_{P b}=0.31 x_{P b}+7.5, y_{C d}=0.50 x_{C d}+0.067$, and $y_{Z n}=0.45 x_{Z n}+47 ;$ the regression for $\mathrm{Cu}$ is not reliable, because the $\mathrm{R} 2$ value is not as high as for the other metals; the regression coefficient can be taken as an estimation of the fraction of each heavy metal remaining after primary settling; the value of the intercept can be interpreted as the average amount of metals added through return flows, and negative values are therefore unrealistic).

\subsection{Potential Improvement of Heavy Metal Removal}

In Figure 4, removal efficiencies for different heavy metals during primary settling are given based on dissolved and particulate fractions in raw and settled wastewater. Calculations of the total removal were made under the idealized assumption that $100 \%$ of heavy metals which are "dissolved" and associated with particles, respectively, could be removed.

Based on these idealized calculations, some indication is given on the potential of enhancing removal of dissolved heavy metals (i.e., applying sorption technologies), or enhancing removal of particle bound metals (i.e., applying coagulation/flocculation).

Enhanced removal of dissolved heavy metals seems to enable improved removal mainly of $\mathrm{Cu}$ and $\mathrm{Ni}$. For $\mathrm{Pb}, \mathrm{Cd}$ and $\mathrm{Zn}$, some of the studies indicate a possible improvement of $50 \%$ or more. Sorption using low-cost sorbents may be an appropriate technology for addressing enhanced removal of these metals. It must be stressed the sorption capacity of the applied sorbent for each metal needs to be considered, and that some of the dissolved heavy metals may be unavailable for sorption (as mentioned in previous discussion on the fractioning between colloidal and truly dissolved/labile heavy metals). In the case of $\mathrm{Cr}$ and $\mathrm{Hg}$, the possible improvement (in total removal by enhancing removal of dissolved metals) seems to be low.

Enhanced removal techniques associated with particles seem to enable improved removal of all heavy metals, though the possible improvement of Ni removal seems to be low in some of the cases. This indicates that coagulation/flocculation may be an appropriate technology for addressing enhanced removal of these metals. 


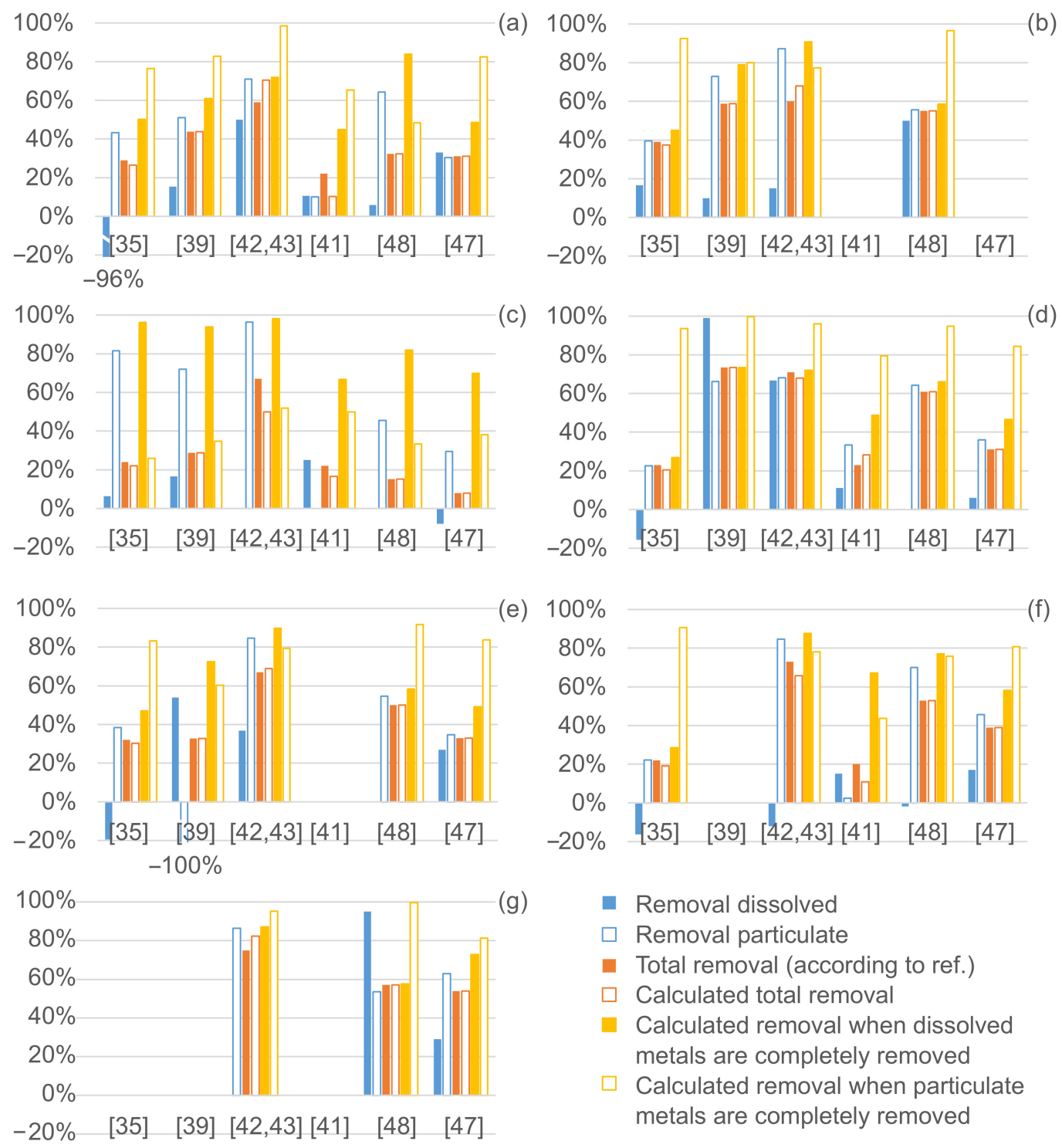

Figure 4. Current removal during primary settling (removal dissolved, particulate, according to reference and calculated removal) and potential for improved removal of dissolved (sorption) and particulate heavy metals (coagulation/flocculation) for: (a) $\mathrm{Cu}$; (b) $\mathrm{Cr}$; (c) Ni; (d) Pb; (e) Cd; (f) Zn; (g) Hg. (Data for As and Ag not available.) The removals according to the references (current dissolved and particulate removal) $([35,39,41-43,47,48])$ are given compared to the calculated removal, which were based on the concentrations given (not on mass flows). Negative values indicate that the concentrations after primary settling were higher than the concentrations before primary settling. Comments regarding sampling points: In $[39,41]$, the influent was sampled before addition of return sludge liquors (i.e., the removal achieved by primary settling might be somewhat underestimated). In [42,43], the influent was sampled after addition of return sludge liquors. In [35], the influent was sampled after return of liquors from sludge digestion and after grit removal but before addition of another supernatant stream. In [48], it is not clear if sampling was performed before or after addition of return sludge liquors. In [47], average values from 16 WWTPs in the UK were given, and most samples of influent wastewater were taken before return flows from sludge treatment. Comment on the "Removal according to reference" compared to "Calculated removal": In $[39,41,47,48]$, the removal given in the references was calculated based on the concentrations in the liquid phase. For $[39,47,48]$, the removal calculated here is thus the same as the removal calculated in the references. The calculated removal calculated for [41] differs from the removal given in the reference because of rounding error (rounded off concentrations were given in the reference). In [35], the removal according to the reference was calculated based on mass flows and thus differs somewhat to the removal calculated here. In $[42,43]$, it is unclear if the removal in the reference was calculated based on mass flow or concentration. 
Furthermore, emerging wastewater treatment technologies with high solids removal efficiency may be beneficial in terms of residual heavy metals in effluents. A treatment technology which is increasingly implemented is membrane bioreactors, which is a compact technology with high effluent quality. Another wastewater treatment technology of interest is mainstream anammox/AB-system (based on two successive biological treatment stages, $\mathrm{A}$ and $\mathrm{B}$, and using no primary clarifier). Mainstream anammox is a technology which is still under development. The advantages of such systems are low external energy requirements and compact construction [96]. With regards to potential heavy metal removal, the solids concentration and removal in the A-stage are typically high which may facilitate removal of both particle-bound and dissolved heavy metals.

\section{Conclusions and Outlook}

The removal of heavy metals during primary settling is determined by the speciation of heavy metals in raw municipal wastewater and the sorption/desorption of heavy metals occurring in the settler. Volatilization is relevant for some metals, e.g., heavy metal $\mathrm{Hg}$ (and semi-metal Sb). Liquors from sludge-thickening and dewatering are often returned to the primary settler. These may increase the heavy metal removal in the primary settler if the concentration of SS is increased or if containing residue of ferric chloride coagulant. Furthermore, changes in redox potential may affect the heavy metal speciation and thus removal. Decreased heavy metal removal may be a result if return liquors contain large amounts of heavy metals associated with fine particles. Heavy metals contained in process chemicals used in secondary or tertiary treatment may contribute to the total heavy metal load entering the primary settler via return liquors. Return sludge from ASP/BNR is sometimes recirculated to the primary settler head, and biomass uptake/sorption may in that case support heavy metal removal.

Mechanisms of heavy metal removal during primary settling are not fully understood. Missing or disparate information on process parameters such as HRT, $\mathrm{pH}$ and composition of return flows makes it hard to generalize the findings from different studies.

Knowledge concerning the speciation of heavy metals is of importance to design appropriate removal technologies. Research is not consistent in considering total and dissolved concentrations $(<0.45$ or $0.2 \mu \mathrm{m})$. Studies which attempted to elucidate heavy metal speciation further applied different methods for pre-processing wastewater before analysis of heavy metals, resulting in different definitions of heavy metal speciation. One definition is particulate, dissolved and truly dissolved and the other definition is particulate, inert and labile. The different ways of defining heavy metal speciation in wastewater make it difficult to compare the results of different studies. However, additional studies including such detailed information regarding heavy metal speciation in influents, effluents and sludge could shed further light on the mechanisms of heavy metal removal in WWTPs.

The variation of total heavy metal concentrations and dissolved fraction in raw municipal wastewater points to a need for site-specific assessment of appropriate technologies for improved heavy metal removal.

Modelling may be helpful to increase the understanding of heavy metal removal during primary settling. So far, full-scale modelling of heavy metal removal during primary settling was made under the assumption that the removal of heavy metals is determined by the distribution of heavy metals between particulate and dissolved fractions in raw wastewater and did not consider the possible sorption/desorption which may occur during the process. Knowledge on the speciation of heavy metals and distribution between particulate and colloidal/truly dissolved or inert/labile may be implemented in models. However, in standard WWTP modelling applied at many WWTPs around the world (the "activated sludge model" [51]), the dynamics of colloidal particles are not described. No literature model for heavy metal speciation/removal from municipal wastewater has considered parameters such as hardness, alkalinity and redox potential of the wastewater. 
Coagulation/flocculation and use of low-cost sorbents were identified as the most promising methods for enhancing heavy metal removal during or directly following primary settling. In the context of decreased heavy metal concentrations in both effluent and sludge from ASP/BNR, the treatment technology should not only enable high heavy metal removal but also: be suitable in wastewater of high solids concentration; have low impact in terms of, e.g., energy use and sludge production; the concurrent removal of $\mathrm{P}$ and organic matter should be low. In the case of coagulation/flocculation, the concurrent removal of organic matter and $P$ needs to be controlled to assure that the $C / N$ ratio and $P$ concentrations are sufficient for subsequent ASP/BNR. Moreover, the possible complexation of heavy metals during ASP/BNR will likely decrease if the MLSS is decreased, which is of importance for the removal from the liquid phase/effluent. Application of low-cost sorbents during primary settling of municipal wastewater was not examined previously, to our knowledge. Based on the heavy metal speciation $(\mathrm{Cd}, \mathrm{Cr}, \mathrm{Cu}, \mathrm{Ni}, \mathrm{Pb}, \mathrm{Zn}$ and $\mathrm{Hg}$ ) and current removal capacity of primary settlers, it is proposed that sorption technologies may be most effective for enhancing the removal of $\mathrm{Cu}$ and $\mathrm{Ni}$, and in some cases of $\mathrm{Pb}, \mathrm{Cd}$ and $\mathrm{Zn}$. Furthermore, the studies concerning heavy metal speciation and removal reviewed here indicate that the fraction of dissolved $\mathrm{Cr}$ and $\mathrm{Cd}$ may likely be smaller at higher total influent heavy metal concentrations. Sorption technologies may thus be less efficient in the case when $\mathrm{Cr}$ and $\mathrm{Cd}$ concentrations are higher. Coagulation/flocculation may be efficient for increasing removal for all the heavy metals studied, with possibly less impact on Ni removal.

Author Contributions: Conceptualization, I.S. and E.T.; formal analysis, I.S.; data curation, I.S.; writing—original draft preparation, I.S.; writing—review and editing, E.T.; supervision, E.T.; project administration, E.T.; funding acquisition, E.T. All authors have read and agreed to the published version of the manuscript.

Funding: This research was funded by VA-kluster Mälardalen, Eskilstuna Energi och Miljö, Vafab Miljö and Mälarenergi.

Institutional Review Board Statement: Not applicable.

Informed Consent Statement: Not applicable.

Data Availability Statement: No new data were created or analyzed in this study. Data sharing is not applicable to this article.

Conflicts of Interest: The authors declare that they have no conflicts of interest. The funders had no role in the design of the study; in the collection, analyses or interpretation of data; in the writing of the manuscript; or in the decision to publish the results.

\section{References}

1. Vareda, J.P.; Valente, A.J.; Durães, L. Assessment of heavy metal pollution from anthropogenic activities and remediation strategies: A review. J. Environ. Manag. 2019, 246, 101-118. [CrossRef] [PubMed]

2. Vardhan, K.H.; Kumar, P.S.; Panda, R.C. A review on heavy metal pollution, toxicity and remedial measures: Current trends and future perspectives. J. Mol. Liq. 2019, 290, 111197. [CrossRef]

3. Libralato, G.; Ghirardini, A.V.; Avezzù, F. To centralise or to decentralise: An overview of the most recent trends in wastewater treatment management. J. Environ. Manag. 2012, 94, 61-68. [CrossRef] [PubMed]

4. Cantinho, P.; Matos, M.; Trancoso, M.A.; Dos Santos, M.M.C. Behaviour and fate of metals in urban wastewater treatment plants: A review. Int. J. Environ. Sci. Technol. 2016, 13, 359-386. [CrossRef]

5. Yoshida, H.; Christensen, T.; Guildal, T.; Scheutz, C. A comprehensive substance flow analysis of a municipal wastewater and sludge treatment plant. Chemosphere 2015, 138, 874-882. [CrossRef] [PubMed]

6. Milieu; WRC; RPA. Environmental, Economic and Social Impacts of the Use of Sewage Sludge on Land Draft Summary; Report 1: Assessment of Existing Knowledge; European Comission/Milieu Ltd.: Brussels, Belgium, 2010.

7. Tao, W.; Sauba, K.; Fattah, K.P.; Smith, J.R. Designing constructed wetlands for reclamation of pretreated wastewater and stormwater. Rev. Environ. Sci. Bio/Technol. 2017, 16, 37-57. [CrossRef]

8. Lindqvist, A.; Sörme, L.; Söderberg, H. Capacity to Influence Sources of Heavy Metals to Wastewater Treatment Sludge. Environ. Manag. 2003, 31, 421-428. [CrossRef] 
9. Hospido, A.; Moreira, M.T.; Fernández-Couto, M.; Feijoo, G. Environmental performance of a municipal wastewater treatment plant. Int. J. Life Cycle Assess. 2004, 9, 261-271. [CrossRef]

10. Ziolko, D.; Martin, O.V.; Scrimshaw, M.D.; Lester, J.N. An Evaluation of Metal Removal During Wastewater Treatment: The Potential to Achieve More Stringent Final Effluent Standards. Crit. Rev. Environ. Sci. Technol. 2011, 41, 733-769. [CrossRef]

11. Santos-Echeandía, J. The fate and transport of trace metals through sewage treatment plant processes. In Sewage Treatment: Uses, Processes and Impact; Stephens, A., Fuller, M., Eds.; Nova Science Publication Inc.: New York, NY, USA, 2009; pp. 1-52. Available online: http: / / www.scopus.com/inward/record.url?eid=2-s2.0-84892042536\&partnerID=40\&md5=97193d874990933d2a394 9b2d4f5dd64 (accessed on 1 September 2020).

12. Hargreaves, A.J.; Constantino, C.; Dotro, G.; Cartmell, E.; Campo, P. Fate and removal of metals in municipal wastewater treatment: A review. Environ. Technol. Rev. 2018, 7, 1-18. [CrossRef]

13. European Comission. Directive 2000/60/EC of the European Parliament and of the Council of 23 October 2000 Establishing a Framework for Community Action in the Field of Water Policy. Off. J. Eur. Union 2000, 327, 1-73.

14. European Comission. Directive 2008/105/EC of the European Parliament and of the Council of 16 December 2008 on Environmental Quality Standards in the Field of Water Policy. Off. J. Eur. Union 2008, 348, 84-97.

15. Irmer, U.; Rau, F.; Arle, J.; Claussen, U.; Mohaupt, V. Ecological Environmental Quality Standards of "River Basin Specific Pollutants" in Surface Waters-Update and Development Analysis of a European Comparison between Member States; WFD CIS Working Group A Ecological Status (ECOSTAT); Publications Office of the European Union: Luxembourg, 2014.

16. European Comission. Council Directive 86/278/EEC of 12 June 1986 on the Protection of the Environment, and in Particular of the Soil, When Sewage Sludge is Used in Agriculture. Off. J. Eur. Union 1986, 181, 6-12.

17. Hudcová, H.; Vymazal, J.; Rozkošný, M. Present restrictions of sewage sludge application in agriculture within the European Union. Soil Water Res. 2019, 14, 104-120. [CrossRef]

18. Clara, M.; Windhofer, G.; Weilgony, P.; Gans, O.; Denner, M.; Chovanec, A.; Zessner, M. Identification of relevant micropollutants in Austrian municipal wastewater and their behaviour during wastewater treatment. Chemosphere 2012, 87, 1265-1272. [CrossRef] [PubMed]

19. Gardner, M.; Comber, S.; Scrimshaw, M.D.; Cartmell, E.; Lester, J.; Ellor, B. The significance of hazardous chemicals in wastewater treatment works effluents. Sci. Total Environ. 2012, 437, 363-372. [CrossRef] [PubMed]

20. Mattsson, A.; Davidsson, F. A strategy for reducing pollutants at source in order to obtain sustainable agricultural recycling of wastewater sludge. Water Sci. Technol. 2012, 66, 1879-1884. [CrossRef]

21. Rule, K.; Comber, S.; Ross, D.; Thornton, A.; Makropoulos, C.; Rautiu, R. Survey of priority substances entering thirty English wastewater treatment works. Water Environ. J. 2006, 20, 177-184. [CrossRef]

22. Barth, M.; Ettinger, J.; Salotto, B.; McDermott, G. Summary report on the effects of heavy metals on the biological treatment processes. Water Pollut. 1965, 37, 86-96.

23. Brown, H.G.; Hensley, C.P.; McKinney, G.L.; Robinson, J.L. Efficiency of Heavy Metals Removal in Municipal Sewage Treatment Plants. Environ. Lett. 1973, 5, 103-114. [CrossRef]

24. Carletti, G.; Fatone, F.; Bolzonella, D.; Cecchi, F. Occurrence and fate of heavy metals in large wastewater treatment plants treating municipal and industrial wastewaters. Water Sci. Technol. 2008, 57, 1329-1336. [CrossRef] [PubMed]

25. Chipasa, K.B. Accumulation and fate of selected heavy metals in a biological wastewater treatment system. Waste Manag. 2003, 23, 135-143. [CrossRef]

26. Davis, J.A., III; Jacknow, J. Heavy metals in wastewater in three urban areas. J. Water Pollut. Control. Fed. 1975, $47,2292-2297$.

27. Stoveland, S.; Astruc, M.; Lester, J.N.; Perry, R. The balance of heavy metals through a sewage treatment works III. Chromium, Nickel and Zinc. Sci. Total Environ. 1979, 12, 25-34. [CrossRef]

28. Lester, J.; Harrison, R.; Perry, R. The balance of heavy metals through a sewage treatment works I. Lead, cadmium and copper. Sci. Total Environ. 1979, 12, 13-23. [CrossRef]

29. Nielsen, J.; Hrudey, S. Metal loadings and removal at a municipal activated sludge plant. Water Res. 1983, 17, $1041-1052$. [CrossRef]

30. Oliveira, A.D.S.; Bocio, A.; Trevilato, T.M.B.; Takayanagui, A.M.M.; Domingo, J.L.; Segura-Muñoz, S.I. Heavy metals in untreated/treated urban effluent and sludge from a biological wastewater treatment plant. Environ. Sci. Pollut. Res. 2007, 14, 483-489. [CrossRef]

31. Sorme, L.; Lagerkvist, R. Sources of heavy metals in urban wastewater in Stockholm. Sci. Total Environ. 2002, 298, 131-145. [CrossRef]

32. Mitsuo, C.; Kiyoshi, M.; Hiroshi, S.; Tadahiro, M. The amount of heavy metals derived from domestic sources in Japan. Water Air Soil Pollut. 1991, 57-58, 829-837.

33. Choubert, J.-M.; Pomiès, M.; Ruel, S.M.; Coquery, M. Influent concentrations and removal performances of metals through municipal wastewater treatment processes. Water Sci. Technol. 2011, 63, 1967-1973. [CrossRef] [PubMed]

34. Toumi, A.; Nejmeddine, A.; Belkoura, M. The Fate of Heavy Metals ( $\mathrm{Zn}, \mathrm{Cu}, \mathrm{Pb}$, Cd and $\mathrm{Cr}$ ) in an Integrated Wastewater Treatment Plant: Two Phase Anaerobic Reactor (RAP)—High Rate Algal Pond (HRAP). Environ. Technol. 2003, $24,153-159$. [CrossRef] [PubMed]

35. Karvelas, M.; Katsoyiannis, A.; Samara, C. Occurrence and fate of heavy metals in the wastewater treatment process. Chemosphere 2003, 53, 1201-1210. [CrossRef] 
36. Lawson, P.S.; Sterritt, R.M.; Lester, J.N. The speciation of metals in sewage and activated sludge effluent. Water Air Soil Pollut. 1984, 21, 387-402. [CrossRef]

37. El Samrani, A.G.; Lartiges, B.S.; Ghanbaja, J.; Yvon, J.; Kohler, A. Trace element carriers in combined sewer during dry and wet weather: An electron microscope investigation. Water Res. 2004, 38, 2063-2076. [CrossRef] [PubMed]

38. Houhou, J.; Lartiges, B.; Montarges-Pelletier, E.; Sieliechi, J.; Ghanbaja, J.; Kohler, A. Sources, nature, and fate of heavy metalbearing particles in the sewer system. Sci. Total Environ. 2009, 407, 6052-6062. [CrossRef]

39. Buzier, R.; Tusseau-Vuillemin, M.-H.; Meriadec, C.M.D.; Rousselot, O.; Mouchel, J.-M. Trace metal speciation and fluxes within a major French wastewater treatment plant: Impact of the successive treatments stages. Chemosphere 2006, 65, 2419-2426. [CrossRef]

40. Gourlay-Francé, C.; Bressy, A.; Uher, E.; Lorgeoux, C. Labile, dissolved and particulate PAHs and trace metals in wastewater: Passive sampling, occurrence, partitioning in treatment plants. Water Sci. Technol. 2011, 63, 1327-1333. [CrossRef]

41. Hargreaves, A.J.; Vale, P.; Whelan, J.; Constantino, C.; Dotro, G.; Campo, P.; Cartmell, E. Distribution of trace metals (Cu, Pb, $\mathrm{Ni}, \mathrm{Zn}$ ) between particulate, colloidal and truly dissolved fractions in wastewater treatment. Chemosphere 2017, 175, 239-246. [CrossRef]

42. Goldstone, M.E.; Kirk, P.W.W.; Lester, J.N. The behaviour of heavy metals during wastewater treatment I. Cadmiun, Chromium and Copper. Sci. Total Environ. 1990, 95, 233-252. [CrossRef]

43. Goldstone, M.; Kirk, P.; Lester, J. The behaviour of heavy metals during wastewater treatment II. Lead, nickel and zinc. Sci. Total Environ. 1990, 95, 253-270. [CrossRef]

44. Goldstone, M.; Atkinson, C.; Kirk, P.; Lester, J. The behaviour of heavy metals during wastewater treatment III. Mercury and arsenic. Sci. Total Environ. 1990, 95, 271-294. [CrossRef]

45. Inna, D.; Lester, J.; Scrimshaw, M.; Cartmell, E. Speciation and fate of copper in sewage treatment works with and without tertiary treatment: The effect of return flows. Environ. Technol. 2013, 35, 1-9. [CrossRef] [PubMed]

46. Cecchini, G.; Cirello, P.; Eramo, B. Partitioning Dynamics and Fate of Metals in an Urban Wastewater Treatment Plant. Environ. Eng. Manag. J. 2015, 14, 1511-1520. [CrossRef]

47. Gardner, M.; Jones, V.; Comber, S.; Scrimshaw, M.D.; Coello-Garcia, T.; Cartmell, E.; Lester, J.; Ellor, B. Performance of UK wastewater treatment works with respect to trace contaminants. Sci. Total Environ. 2013, 456-457, 359-369. [CrossRef] [PubMed]

48. Oliver, B.G.; Cosgrove, E.G. The efficiency of heavy metal removal by a conventional activated sludge treatment plant. Water Res. 1974, 8, 869-874. [CrossRef]

49. Chen, K.Y.; Young, C.S.; Jan, T.K.; Rohatgi, N. Trace metals in wastewater effluents. J. Water Pollut. Control. Fed. 1974, 46, 2663-2675.

50. Modin, O.; Persson, F.; Wilén, B.-M.; Hermansson, M. Nonoxidative removal of organics in the activated sludge process. Crit. Rev. Environ. Sci. Technol. 2016, 46, 1-38. [CrossRef]

51. Pomiès, M.; Choubert, J.-M.; Wisniewski, C.; Coquery, M. Modelling of micropollutant removal in biological wastewater treatments: A review. Sci. Total Environ. 2013, 443, 733-748. [CrossRef]

52. Kempton, S.; Sterritt, R.; Lester, J. Heavy metal removal in primary sedimentation I. The influence of metal solubility. Sci. Total Environ. 1987, 63, 231-246. [CrossRef]

53. Petrie, B.; McAdam, E.J.; Lester, J.N.; Cartmell, E. Assessing potential modifications to the activated sludge process to improve simultaneous removal of a diverse range of micropollutants. Water Res. 2014, 62, 180-192. [CrossRef]

54. Dionisi, D.; Bornoroni, L.; Mainelli, S.; Majone, M.; Pagnanelli, F.; Papini, M.P. Theoretical and Experimental Analysis of the Role of Sludge Age on the Removal of Adsorbed Micropollutants in Activated Sludge Processes. Ind. Eng. Chem. Res. 2008, 47, 6775-6782. [CrossRef]

55. Ren, Y.; Wang, J.; Li, H.; Zhang, J.; Qi, P.; Hu, Z. Nitrous oxide and methane emissions from different treatment processes in full-scale municipal wastewater treatment plants. Environ. Technol. 2013, 34, 2917-2927. [CrossRef]

56. Xiao, H.; Zhang, S.; Zhai, J.; He, Q.; Mels, A.; Ning, K.; Liu, J. Retention and distribution of Cu, Pb, Cr, and Zn in a full-scale hybrid constructed wetland receiving municipal sewage. Water Sci. Technol. 2013, 67, 2257-2264. [CrossRef]

57. Comte, S.; Guibaud, G.; Baudu, M. Biosorption properties of extracellular polymeric substances (EPS) towards Cd, Cu and Pb for different $\mathrm{pH}$ values. J. Hazard. Mater. 2008, 151, 185-193. [CrossRef]

58. Guibaud, G.; van Hullebusch, E.; Bordas, F. Lead and cadmium biosorption by extracellular polymeric substances (EPS) extracted from activated sludges: pH-sorption edge tests and mathematical equilibrium modelling. Chemosphere 2006, 64, 1955-1962. [CrossRef]

59. Parker, W.J.; Monteith, H.D.; Bell, J.P.; Melcer, H.; Mac Berthouex, P. Comprehensive fate model for metals in municipal wastewater. J. Environ. Eng. 1994, 20, 1266-1283. [CrossRef]

60. Wang, J.; Huang, C.; Allen, H.E. Predicting metals partitioning in wastewater treatment plant influents. Water Res. 2006, 40, 1333-1340. [CrossRef]

61. Katsoyiannis, A.; Samara, C. The fate of dissolved organic carbon (DOC) in the wastewater treatment process and its importance in the removal of wastewater contaminants. Environ. Sci. Pollut. Res. 2007, 14, 284-292. [CrossRef]

62. Barret, M.; Patureau, D.; Latrille, E.; Carrère, H. A three-compartment model for micropollutants sorption in sludge: Methodological approach and insights. Water Res. 2010, 44, 616-624. [CrossRef]

63. Cloutier, F.; Jalby, G.; Lessard, P.; Vanrolleghem, P.A. Modélisation dynamique du comportement des métaux lourds des stations d'épuration. J. Water Sci. 2009, 22, 461-471. [CrossRef] 
64. Fu, F.; Wang, Q. Removal of heavy metal ions from wastewaters: A review. J. Environ. Manag. 2011, 92, 407-418. [CrossRef] [PubMed]

65. Carolin, C.F.; Kumar, P.S.; Saravanan, A.; Joshiba, G.J.; Naushad, M. Efficient techniques for the removal of toxic heavy metals from aquatic environment: A review. J. Environ. Chem. Eng. 2017, 5, 2782-2799. [CrossRef]

66. Barakat, M. New trends in removing heavy metals from industrial wastewater. Arab. J. Chem. 2011, 4, 361-377. [CrossRef]

67. Tong, Y.; McNamara, P.J.; Mayer, B.K. Adsorption of organic micropollutants onto biochar: A review of relevant kinetics, mechanisms and equilibrium. Environ. Sci. Water Res. Technol. 2019, 5, 821-838. [CrossRef]

68. Wei, D.; Ngo, H.H.; Guo, W.; Xu, W.; Du, B.; Khan, M.S.; Wei, Q. Biosorption performance evaluation of heavy metal onto aerobic granular sludge-derived biochar in the presence of effluent organic matter via batch and fluorescence approaches. Bioresour. Technol. 2018, 249, 410-416. [CrossRef]

69. Muddemann, T.; Haupt, D.; Sievers, M.; Kunz, U. Electrochemical Reactors for Wastewater Treatment. ChemBioEng Rev. 2019, 6, 142-156. [CrossRef]

70. Guo, Z.; Tang, D.; Liu, X.; Zheng, Z. Gamma irradiation-induced Cd2+ and Pb2+ removal from different kinds of water. Radiat. Phys. Chem. 2008, 77, 1021-1026. [CrossRef]

71. Väänänen, J. Microsieving in Municipal Wastewater Treatment: Chemically Enhanced Primary and Tertiary Treatment. Ph.D. Thesis, Lund University, Lund, Sweden, 2017.

72. Loeb, S.K.; Alvarez, P.J.J.; Brame, J.A.; Cates, E.L.; Choi, W.; Crittenden, J.; Dionysiou, D.D.; Li, Q.; Li-Puma, G.; Quan, X.; et al. The Technology Horizon for Photocatalytic Water Treatment: Sunrise or Sunset? Environ. Sci. Technol. 2019, 53, $2937-2947$. [CrossRef] [PubMed]

73. Hargreaves, A.J.; Vale, P.; Whelan, J.; Alibardi, L.; Constantino, C.; Dotro, G.; Cartmell, E.; Campo, P. Coagulation-flocculation process with metal salts, synthetic polymers and biopolymers for the removal of trace metals $(\mathrm{Cu}, \mathrm{Pb}, \mathrm{Ni}, \mathrm{Zn})$ from municipal wastewater. Clean Technol. Environ. Policy 2018, 20, 393-402. [CrossRef]

74. Hargreaves, A.J.; Vale, P.; Whelan, J.; Alibardi, L.; Constantino, C.; Dotro, G.; Cartmell, E.; Campo, P. Impacts of coagulationflocculation treatment on the size distribution and bioavailability of trace metals $(\mathrm{Cu}, \mathrm{Pb}, \mathrm{Ni}, \mathrm{Zn})$ in municipal wastewater. Water Res. 2018, 128, 120-128. [CrossRef] [PubMed]

75. Bailey, S.E.; Olin, T.J.; Bricka, R.; Adrian, D. A review of potentially low-cost sorbents for heavy metals. Water Res. 1999, 33, 2469-2479. [CrossRef]

76. Kurniawan, T.A.; Chan, G.Y.; Lo, W.-H.; Babel, S. Comparisons of low-cost adsorbents for treating wastewaters laden with heavy metals. Sci. Total Environ. 2006, 366, 409-426. [CrossRef]

77. Wan Ngah, W.S.; Hanafiah, M.A.K.M. Removal of heavy metal ions from wastewater by chemically modified plant wastes as adsorbents: A review. Bioresour. Technol. 2008, 99, 3935-3948. [CrossRef]

78. Smith, K.; Fowler, G.; Pullket, S.; Graham, N. Sewage sludge-based adsorbents: A review of their production, properties and use in water treatment applications. Water Res. 2009, 43, 2569-2594. [CrossRef]

79. Qin, H.; Hu, T.; Zhai, Y.; Lu, N.; Aliyeva, J. The improved methods of heavy metals removal by biosorbents: A review. Environ. Pollut. 2020, 258, 113777. [CrossRef]

80. Niazi, N.; Murtaza, B.; Bibi, I.; Shahid, M.; White, J.; Nawaz, M.; Bashir, S.; Shakoor, M.; Choppala, G.; Wang, H. Removal and Recovery of Metals by Biosorbents and Biochars Derived from Biowastes. Environ. Mat. Waste 2016, 149-177. [CrossRef]

81. Salman, M.; Athar, M.; Farooq, U. Biosorption of heavy metals from aqueous solutions using indigenous and modified lignocellulosic materials. Rev. Environ. Sci. Bio/Technol. 2015, 14, 211-228. [CrossRef]

82. Mohan, D.; Sarswat, A.; Ok, Y.S.; Pittman, C.U. Organic and inorganic contaminants removal from water with biochar, a renewable, low cost and sustainable adsorbent-A critical review. Bioresour. Technol. 2014, 160, 191-202. [CrossRef]

83. Chen, T.; Zhou, Z.; Han, R.; Meng, R.; Wang, H.; Lu, W. Adsorption of cadmium by biochar derived from municipal sewage sludge: Impact factors and adsorption mechanism. Chemosphere 2015, 134, 286-293. [CrossRef]

84. Yin, Q.; Zhang, B.; Wang, R.; Zhao, Z. Biochar as an adsorbent for inorganic nitrogen and phosphorus removal from water: A review. Environ. Sci. Pollut. Res. 2017, 24, 26297-26309. [CrossRef]

85. Peng, G.; Jiang, S.; Wang, Y.; Zhang, Q.; Cao, Y.; Sun, Y.; Zhang, W.; Wang, L. Synthesis of Mn/Al double oxygen biochar from dewatered sludge for enhancing phosphate removal. J. Clean. Prod. 2020, 251, 119725. [CrossRef]

86. La Cour Jansen, J.; Arvin, E.; Henze, M.; Harremoës, P. Wastewater Treatment-Biological and Chemical Processes, 4th ed.; Polyteknisk Forlag: Copenhagen, Denmark, 2019; p. 372.

87. Johnson, P.D.; Girinathannair, P.; Ohlinger, K.N.; Ritchie, S.; Teuber, L.; Kirby, J. Enhanced removal of heavy metals in primary treatment using coagulation and flocculation. Water Environ. Res. 2008, 80, 472-479. [CrossRef]

88. El Samrani, A.G.; Lartiges, B.S.; Villiéras, F. Chemical coagulation of combined sewer overflow: Heavy metal removal and treatment optimization. Water Res. 2008, 42, 951-960. [CrossRef] [PubMed]

89. Metcalf, E. Wastewater Engineering: Treatment and Resource Recovery, 5th ed.; McGraw-Hill: New York, NY, USA, 2014.

90. Pan, B.; Pan, B.; Zhang, W.; Lv, L.; Zhang, Q.; Zheng, S. Development of polymeric and polymer-based hybrid adsorbents for pollutants removal from waters. Chem. Eng. J. 2009, 151, 19-29. [CrossRef]

91. Vimala, R.; Escaline, J.L.; Sivaramakrishnan, S. Characterization of self-assembled bioflocculant from the microbial consortium and its applications. J. Environ. Manag. 2020, 258, 110000. [CrossRef] [PubMed] 
92. Liu, Y.; Lam, M.C.; Fang, H.H. Adsorption of heavy metals by EPS of activated sludge. Water Sci. Technol. 2001, 43, 59-66. [CrossRef] [PubMed]

93. Sun, Y.; Shah, K.J.; Sun, W.; Zheng, H. Performance evaluation of chitosan-based flocculants with good pH resistance and high heavy metals removal capacity. Sep. Purif. Technol. 2019, 215, 208-216. [CrossRef]

94. Hargreaves, A.J.; Vale, P.; Whelan, J.; Constantino, C.; Dotro, G.; Cartmell, E. Mercury and antimony in wastewater: Fate and treatment. Water Air Soil Pollut. 2016, 227, 89. [CrossRef] [PubMed]

95. Santos, A.; Judd, S. The fate of metals in wastewater treated by the activated sludge process and membrane bioreactors: A brief review. J. Environ. Monit. 2010, 12, 110-118. [CrossRef]

96. Hoekstra, M.; Geilvoet, S.P.; Hendrickx, T.L.G.; Kip, C.S.V.E.T.; Kleerebezem, R.; Van Loosdrecht, M.C.M. Towards mainstream anammox: Lessons learned from pilot-scale research at WWTP Dokhaven. Environ. Technol. 2019, 40, 1721-1733. [CrossRef] 